\title{
Corn and Soybeans in a Strip Intercropping System: Crop Growth Rates, Radiation Interception, and Grain Yield Components
}

\author{
Diego Verdelli, ${ }^{1}$ Horacio A. Acciaresi, ${ }^{2}$ and Eduardo S. Leguizamón ${ }^{1}$ \\ ${ }^{1}$ Departamento de Sistemas de Producción Vegetal, Facultad de Ciencias Agrarias, Universidad Nacional de Rosario, Santa Fe, CC 14, \\ S2125ZAA, Zavalla, Argentina \\ ${ }^{2}$ Cátedra de Cereales, Facultad de Ciencias Agrarias y Forestales, Universidad Nacional de La Plata, CC 31, B1900, La Plata, Argentina
}

Correspondence should be addressed to Horacio A. Acciaresi, acciaresi@gmail.com

Received 17 June 2011; Accepted 16 January 2012

Academic Editor: David Clay

Copyright (c) 2012 Diego Verdelli et al. This is an open access article distributed under the Creative Commons Attribution License, which permits unrestricted use, distribution, and reproduction in any medium, provided the original work is properly cited.

\begin{abstract}
Crop growth rates (CGR), radiation interception (IPAR), yields, and their components were determined in two crops monocultures (using one corn and two soybean genotypes) and in intercropped "strips," during three growing seasons. Corn yield in the strips significantly increased in the three seasons (13-16\%) as compared to that in the monocultures. This response was due to increased yield in corn plants of the border rows of the strips, which was highly correlated to an increased IPAR, allowing high CGR at critical crop stages. As a result, more dry matter was partitioned to grain and also an increased number of ears per plant were generated. Conversely, yields of soybeans in the strips were 2 to $11 \%$ lower than that in the monocultures, with variable significance depending on soybean cultivar and/or year. Grain number per unit area was the yield component most closely associated to yield variation in both crops. We believe that if yield components of this system are more closely identified, more appropriate genotypes will fit into strip intercropping, thus contributing to the spread of this technique and thus to the sustainability of actual massive monocultured agricultural systems.
\end{abstract}

\section{Introduction}

A crop association essentially consists of growing two or more crops in the same area of land at the same time. Supported by the conventional accepted niche theory [1], the aim of this crop system is to optimize factors and environmental resources usage [2], thus leading to an increased yield output of the mixture. In strip intercropping, the width of the strip needs to be wide enough to allow seeding and harvesting operations although narrow enough to allow the interaction of the components of the mixture to occur [3]. Depending on the scenario and the circumstances, interaction is not only dependent on the availability of resources but also on the structure of the crops and cultivars used.

Corn grain yield is the result of the grain weight (GW) multiplied by the grain number per unit area (GNUA) [4]. GNUA also depends on the crop physiological condition during the critical period [5]. As crop growth rate (CGR) and also plant growth rate (PGR) increases, the number of grain fixed within the flowering period also increases [6]. Hence, this relationship is a good indicator of the crop ability for grain fixation, under variable environmental (water, nitrogen, and radiation) conditions [7]. The abovedescribed relationship, also influenced by the genotype, is highly related to two factors: (i) irradiance availability and (ii) crop architecture.

Yield is also defined as the product of GW by GNUA in soybeans. Contrary to corn, subcomponents of GNUA are defined within a very wide range of time of the crop cycle, from crop emergence (VE) to the latest differentiated pods (R2). Adverse environmental conditions in the earlier stages of the crop may be compensated, if the quality of the environment improves later on, providing the final grain number is not affected [8]. Thus, the critical period in soybeans is not as precise as it is in corn, since it is related to the grain filling period and also to partial compensations in GW. Temperature and radiation during the critical period are key factors controlling the crop growth rate (CGR) and 
the grain number per unit area (GNUA) under nonrestricted soil conditions.

In the nonirrigated, extensive summer crop production systems of Argentina, radiation is the key factor in determining yields, providing no nutrients and rainfall shortage occur. Since the intercepted radiation (IPAR) and its efficiency (Radiation Use Efficiency (RUE)) are central factors in defining the plant yield outputs, we studied the growth and the variations in yields and its components in both crops (one corn, two soybeans genotypes) under monocultures and in strips intercropping systems, since we believe that our findings may contribute to the selection of traits more suitable for genotypes, thus contributing to local knowledge generation, the basis for the adoption of this system.

\section{Material and Methods}

2.1. Experimental Conditions. Experiments were conducted in Monte Buey, Argentina ( $32^{\circ} 94^{\prime} 41^{\prime \prime}$ S $\left.62^{\circ} 58^{\prime} 97^{\prime \prime} \mathrm{W}\right)$, during 2006-2007, 2007-2008, and 2008-2009 (C1, C2, and C3, resp.), in a highly productive typic Argiudol soil [9], cultivated under direct drilling technique since 1996.

The experimental units consisted in 36 rows, $8 \mathrm{~m}$ length $\times 19 \mathrm{~m}$ width plots, with an interrow spacing of $0.52 \mathrm{~m}$. Treatments included the following crops monocultures: corn (intermediate cycle single DK 684 hybrid, 665-685 degreedays since emergence to female flowering, 119 Julian days to relative maturity) and two soybean genotypes: MG III, cv DM 3700RR (126/145 Julian days to R8), and MG V, cV DM 4800RR (134/155 Julian days to R8) and also "strips" of both crops: in corn strips corn was planted in the 12 central rows, with 12 rows of soybeans on each side; in the soybean strips, soybeans were planted in the 12 central rows with 12 rows of corn on each side. Thus, a total of seven treatments were tested: three monocultures (one corn, two soybeans), two corn strips bordered by soybeans (MG III or V), and two soybean strips (MG III or V) bordered by corn.

In all treatments, corn was planted on October the 12th $(\mathrm{C} 1, \mathrm{C} 2)$ and October the 14th (C3). Corn stand density was 8.2 seeds $\mathrm{m}^{-2}$. In all treatments, soybeans were planted either in the monocultures or in the strips on November 10th $(\mathrm{C} 1)$, November 16th (C2), and November 9th (C3). Soybean stand density was 24 seeds $\mathrm{m}^{-2}$. All plots were planted with the rows oriented east-west.

Treatments were placed under a complete randomized block design with four replications. Nitrogen (UAN-N-P-K. 32-0-0, $200 \mathrm{Kg} \mathrm{N} \mathrm{ha}^{-1}$ ) and phosphorus (Mono-ammonium phosphate) $12-52-0,24 \mathrm{Kg} \mathrm{N}^{-1}$, and $104 \mathrm{Kg} \mathrm{P} \mathrm{ha}^{-1}$ ), plus $\mathrm{SO}_{4} \mathrm{Ca}, 350 \mathrm{Kg} \mathrm{ha}^{-1}$ were, respectively, band and broadcast applied every year. Insect and weed management were carried out following recommended standards in the area to allow maximum crop yield potential. Temperature, radiation, and rainfall data were recorded with an automatic weather station located at $1500 \mathrm{~m}$ from the experiment site.

2.2. Irradiance. Radiation interception was measured soon after crop emergence and every 20 days until physiological maturity. A 1 m, Line Quantum Sensor (LI-191SA, LI-COR,
Lincoln, NE) was used. The sensor was placed in the interrow (to capture PAR transmitted to the soil) and also placed above the crop canopy (to measure the total PAR received by the crop). In the strip treatments, additional measurements were made at different crop heights not only in the border row but also in the central row of each plot. Intercepted PAR (IPAR) by the crop was calculated according to Gallo [10]:

$$
\mathrm{IPAR}=I_{o}-\mathrm{Rt}
$$

where IPAR is the PAR intercepted by the crop, $I_{o}$ is the total radiation above the crop canopy, and $\mathrm{Rt}$ is the radiation at soil level. IPAR during crop cycle was calculated as the area under the curve.

RUE was calculated as the slope of the total biomass regressed to the IPAR captured through the complete crop cycle in both crops [11] and calculated as dry matter (g) per unit of intercepted PAR radiation $\left(\mathrm{Mj}^{-1}\right)$, in $\mathrm{C} 1, \mathrm{C} 2$, and $\mathrm{C} 3$.

2.3. Crop Growth Rate. CGR was determined at six sample dates from crop emergence to physiological maturity, by using plant dry weight of the strip and also of the monocultures. In strips, plants of rows $1,3,5,7,9$, and 11 were used. All plants were dried at $65^{\circ} \mathrm{C}$ in an air circulating oven, during 72 hours. The following formula was used to calculate the growth rate [12]:

$$
\mathrm{CGR}=\frac{W_{2}-W_{1}}{t_{2}-t_{1}},
$$

where CGR is the crop growth rate $\left(\mathrm{g} \mathrm{m}^{-2} \mathrm{~d}^{-1}\right), W$ is aboveground plant biomass $(\mathrm{g})$ at $t_{1}$ and $t_{2}$ days after crop sowing.

2.4. Yield. Plants randomly selected within the central four rows in the monoculture plots and those remaining of previous harvests in the strip plots, located within the central $3 \mathrm{~m}$ of every single row, were cut and then threshed in an experimental grain thresher. In soybeans, total pods number was registered and also grain weight determined. Crop yields in the strips were then calculated as the average yield of 12 rows and compared with yields obtained in the monocultures. All grain weights were corrected to the standard $13.5 \%$ grain humidity and reported as $\mathrm{kg} \mathrm{ha}^{-1}$.

2.5. Yield Components: Corn. Ears per plant were calculated by dividing the total number of ears per plant by plant density. Grain dry weight (GW) was estimated by using the weight of 500 grains, grain number per unit area (GNUA) was calculated as a yield divided by GW, and ear number per unit area (ENUA) was calculated by multiplying plant density with ears per plant (ENP). The grain number per ear was calculated as follows:

$$
\mathrm{GNE}=\frac{\mathrm{GNUA}}{\mathrm{PN} * \mathrm{ENP}},
$$

where GNE is the number of grains per ear, GNUA is the number of grains per unit area, $\mathrm{PN}$ is the number of plants per unit area, and ENP the number of ears per plant. The number of grains per plant (GNP) was calculated by multiplying ENP by GNE. 


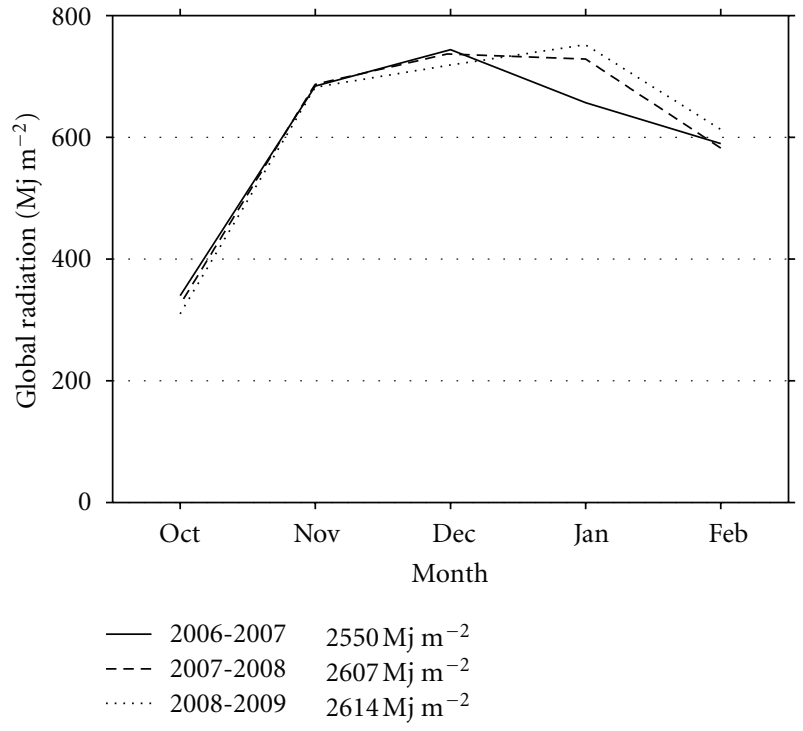

(a)

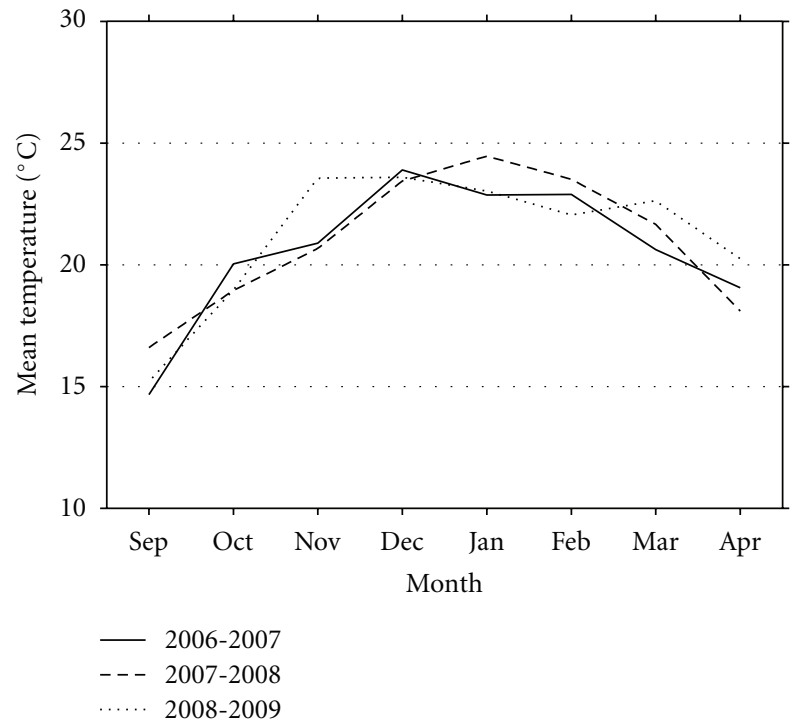

(b)

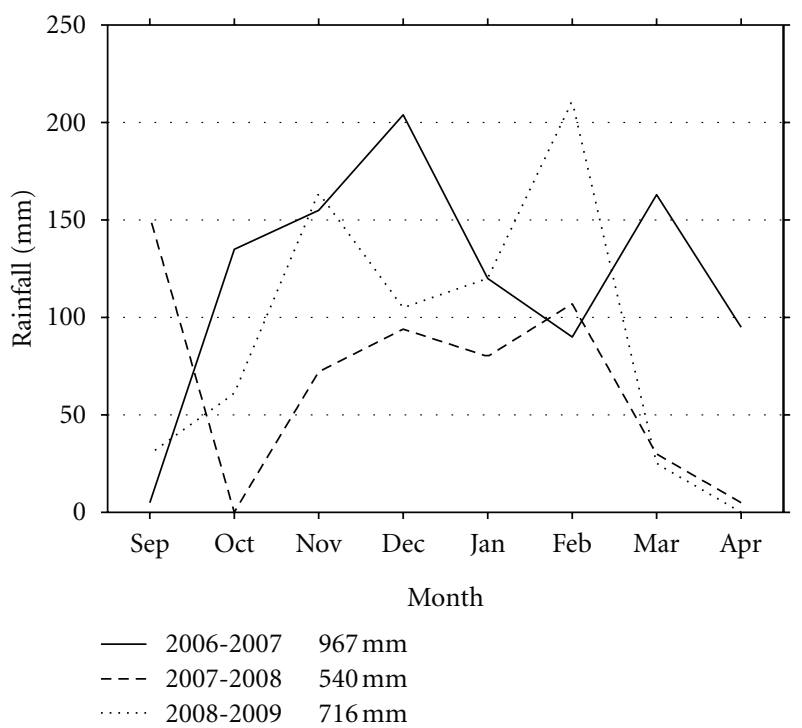

(c)

FIgURE 1: Weather conditions: PAR (a), mean air temperature (b), and rainfall (c) during crop cycles in C1, C2, and C3.

2.6. Yield Components: Soybeans. Pod number per plant (PNP) was calculated as the average number of pods of 10 plants randomly selected in every harvested row. The number of pods per unit area (PUA) was calculated by multiplying PNP by plant density (PD) at harvest time. Grain dry weight was estimated by weighing 500 grains. The number of grains per unit area (GNUA) was determined by dividing grain yield by grain dry weight (GDW). The number of grains per pod (GPP) was determined by dividing GNUA by pod number.

2.7. Statistical Analysis. Experimental design consisted in seven treatments under a complete randomized block design with four replicates. Variables were evaluated by multivariate ANOVA. For those variables sequentially measured along the crop cycle (e.g., plant dry weight, leaf area index), a second-order interaction between treatments and year at each harvest time was calculated. Mean separations were made using Least Significant Difference (LSD) test. All comparisons were set at $P<0.05$. The statistical package Statgraphics Plus (v.5.1) was used. Variables or indices showing curvilinear responses were analyzed using Graph Pad Prism (Golden Software Inc.) statistic software package.

\section{Results and Discussion}

Global radiation and air temperature showed a similar pattern during $\mathrm{C} 1, \mathrm{C} 2$, and $\mathrm{C} 3$ (Figures $1(\mathrm{a})$ and 1(b)): a steady-increase pattern was clearly evident from midSeptember to early January and a slight decrease (as crops 
TABLE 1: PAR interception (IPAR) $\left(\mathrm{Mj} \mathrm{m}^{-2}\right)$. Locations 1,7 , or 12, corresponds to the northern, central, and southern rows, respectively. In monoculture, measurements were made in the center of the plot. Means in a column followed by same letter are not significantly different $(P<0.05)$.

\begin{tabular}{|c|c|c|c|c|}
\hline & Location (rows) & Total IPAR(Mj m²) & $\begin{array}{l}\text { IPAR around silking } \\
\left(\mathrm{Mj} \mathrm{m}^{-2}\right)\end{array}$ & $\begin{array}{c}\text { IPAR after silking-R6 } \\
\left(\mathrm{Mj} \mathrm{m}^{-2}\right)\end{array}$ \\
\hline \multirow{3}{*}{ Strip Corn + soybean MG III } & 1 & $1275.8 \mathrm{a}$ & $408.4 \mathrm{a}$ & $654.6 a$ \\
\hline & 7 & $1000.7 b$ & $320.1 b$ & $515.5 b$ \\
\hline & 12 & $1101.4 \mathrm{a}$ & $386.9 \mathrm{a}$ & $615.6 a$ \\
\hline \multirow{3}{*}{ Strip Corn + soybean MG V } & 1 & $1277.2 \mathrm{a}$ & $408.9 \mathrm{a}$ & $655.7 \mathrm{a}$ \\
\hline & 7 & $1001.6 b$ & $320.4 b$ & $515.8 b$ \\
\hline & 12 & $1156.9 \mathrm{a}$ & $387.1 \mathrm{a}$ & $616.4 \mathrm{a}$ \\
\hline Corn monoculture & Center & $1010.3 \mathrm{~b}$ & $323.9 \mathrm{~b}$ & $521.2 \mathrm{~b}$ \\
\hline \multirow{3}{*}{ Strip soybean MG III + Corn } & 1 & $868.6 \mathrm{c}$ & - & $379.9 \mathrm{c}$ \\
\hline & 7 & $1190.1 \mathrm{~d}$ & - & $466.3 \mathrm{~d}$ \\
\hline & 12 & $1165.5 \mathrm{~d}$ & - & $459.0 \mathrm{~d}$ \\
\hline \multirow[t]{2}{*}{ Soybean MG III monoculture } & Center & $1229.7 d$ & - & $477.0 \mathrm{~d}$ \\
\hline & 1 & $896.9 c$ & - & $394.5 c$ \\
\hline \multirow[t]{2}{*}{ Strip soybean MG V + corn } & 7 & $1227.6 \mathrm{~d}$ & - & $484.2 \mathrm{~d}$ \\
\hline & 12 & $1202.2 \mathrm{~d}$ & - & $476.7 \mathrm{~d}$ \\
\hline Soybean MG V monoculture & Center & $1268.3 \mathrm{~d}$ & - & $495.4 \mathrm{~d}$ \\
\hline
\end{tabular}

started accumulating biomass in reproductive tissues) from mid-January to March-April. Global radiation accumulated $2590 \mathrm{MJ} \mathrm{m}^{-2}$ in the whole season.

Total rainfall and rainfall frequency patterns were clearly different in each year, with $\mathrm{C} 2$ (with a total rainfall of $540 \mathrm{~mm}$ ) being the driest year as compared to the wetter C1 $(967 \mathrm{~mm})$ and C3 (716 mm) (Figure 1(c)).

3.1. Irradiance. In the strip, IPAR was significantly higher in the border rows than in the center rows and also higher than in the monoculture. These significant differences occured around $700 \mathrm{DD}$ (reproductive stage initiation) and more consistently in north row (row 1 ) than in the south row (row 12), in both corn-soybeans (MG III and V) strips during the three seasons. IPAR was lower in the north rows (row 1) of soybean strips due to the shadow produced by adjacent corn plants (Table 1).

\section{Corn}

4.1. IPAR and CGR. The relationships between CGR around flowering and IPAR in corn strips with soybeans MG III are shown in Figures 2(a), 2(c), and 2(e) and in corn strips with MG V and in Figures 2(b), 2(d), and 2(f). GCR of the plants located in border rows was higher $(P<0.05)$ as compared to that of plants growing in the inner rows or in the monoculture. This enhanced CGR in corn plants of outer rows was measured in both corn-soybeans associations during $\mathrm{C} 1, \mathrm{C} 2$, and $\mathrm{C} 3$.

Since growing conditions around flowering are of major importance in determining crop yield, the greater IPAR may explain the increased values of CGR. Following the same reasoning, Kantolic and Satorre [13] found that 58\% of CGR was explained by differences in the IPAR at R1 crop stage.
TABle 2: RUE $\left(\mathrm{g} \mathrm{Mj}^{-1}\right)$ in monocultures and intercropped, during $\mathrm{C} 1, \mathrm{C} 2$ and $\mathrm{C} 3$.

\begin{tabular}{|c|c|c|c|c|}
\hline \multirow{2}{*}{ Treatments } & \multirow{2}{*}{ Location (rows) } & \multicolumn{3}{|c|}{$\operatorname{RUE}\left(\mathrm{g} \mathrm{Mj}^{-1}\right)$} \\
\hline & & $\mathrm{C} 1$ & $\mathrm{C} 2$ & $\mathrm{C} 3$ \\
\hline \multirow{2}{*}{$\begin{array}{l}\text { Strip corn } \\
\text { Soybean III }\end{array}$} & Row 1 & 3,25 (a) & $3,80(a)$ & 3,83 (a) \\
\hline & Row 7 & 3,16 (a) & $3,73(a)$ & $4,14(\mathrm{a})$ \\
\hline \multirow{2}{*}{$\begin{array}{l}\text { Strip corn } \\
\text { Soybean V }\end{array}$} & Row 1 & $3,48(a)$ & $3,80(a)$ & 3,95 (a) \\
\hline & Row 7 & $3,00(\mathrm{a})$ & $3,72(a)$ & 4,27 (a) \\
\hline Corn monoculture & Center & 3,19 (a) & $3,22(a)$ & 4,04 (a) \\
\hline \multirow{2}{*}{$\begin{array}{l}\text { Strip soybean III } \\
\text { Corn }\end{array}$} & Row 1 & $0,94(b)$ & $0,58(b)$ & 0,79 (b) \\
\hline & Row 7 & $1,64(b)$ & $0,52(b)$ & $1,12(b)$ \\
\hline $\begin{array}{l}\text { Soybean III } \\
\text { monoculture }\end{array}$ & Center & 0,98 (b) & 0,47 (b) & $1,00(b)$ \\
\hline \multirow{2}{*}{$\begin{array}{l}\text { Strip soybean V } \\
\text { Corn }\end{array}$} & Row 1 & $1,21(b)$ & $0,55(b)$ & 0,94 (b) \\
\hline & Row 7 & $1,23(\mathrm{~b})$ & $0,50(b)$ & $0,92(b)$ \\
\hline $\begin{array}{l}\text { Soybean V } \\
\text { monoculture }\end{array}$ & Center & 1,18 (b) & 0,46 (b) & $0,94(b)$ \\
\hline
\end{tabular}

In our experiments, CGR reached $60 \mathrm{~g} \mathrm{DW} \mathrm{m}^{-2} \mathrm{~d}^{-1}$ when IPAR values ranged from 14 to $16 \mathrm{Mj} \mathrm{m}^{-2} \mathrm{~d}^{-1}$ in row 1 . This figure is similar to those reported by Lindquist et al. [11] and Tollenaar and Migus [14], but higher than those found by Andrade et al. [6] which was also done in Argentina, although in monocultures and at a lower latitude. Increased IPAR levels in row 1 are closely associated to a higher CGR, which seems to be the consequence of higher PAR capture by nonshaded leaves.

4.2. Radiation Use Efficiency (RUE). RUE in the strips did not differ to that in the monocultures $(P<0.05)$ (Table 2$)$. 


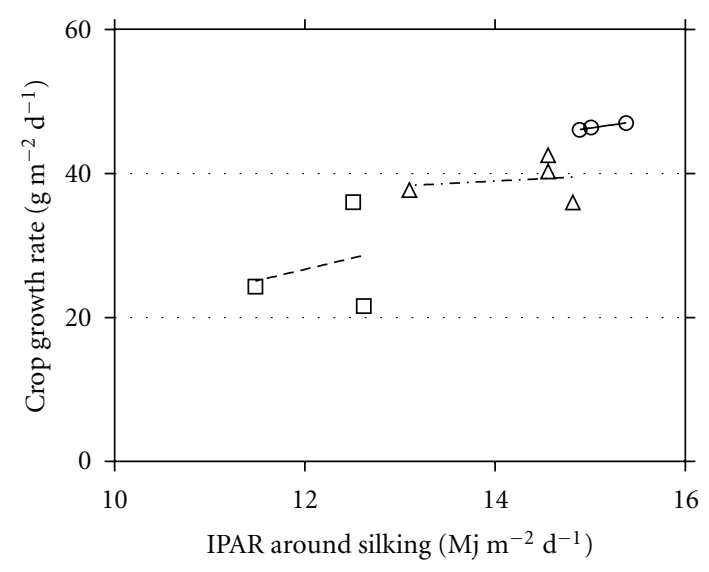

(a)

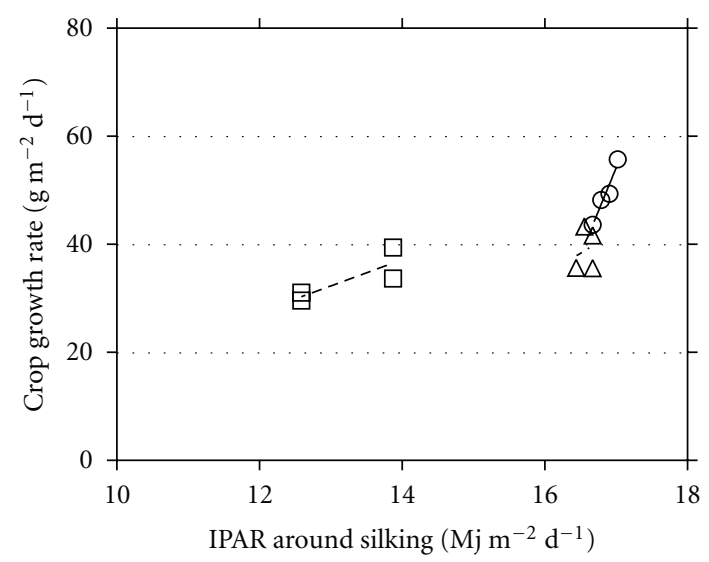

(c)

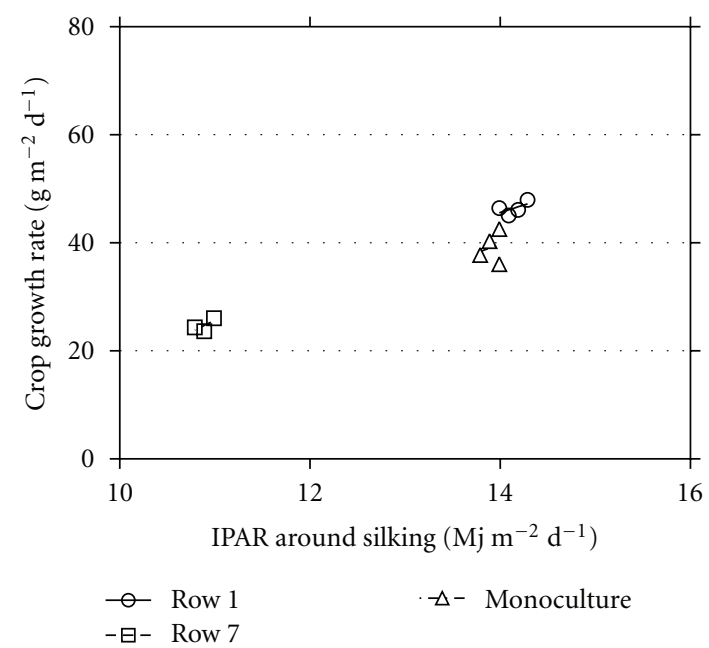

(e)

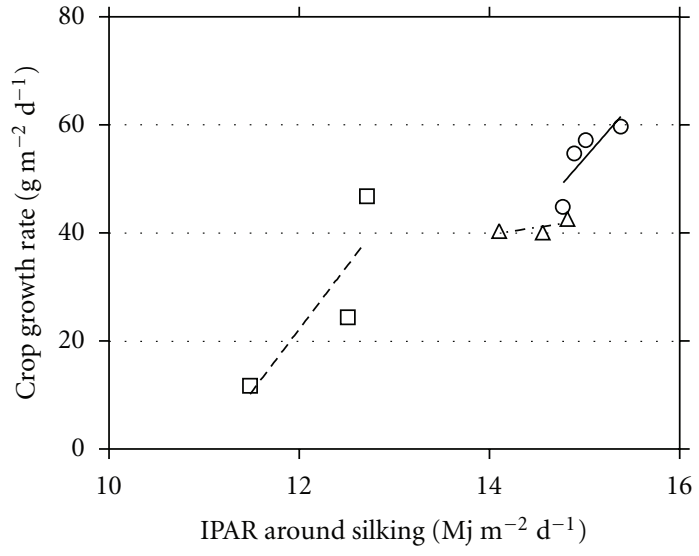

(b)

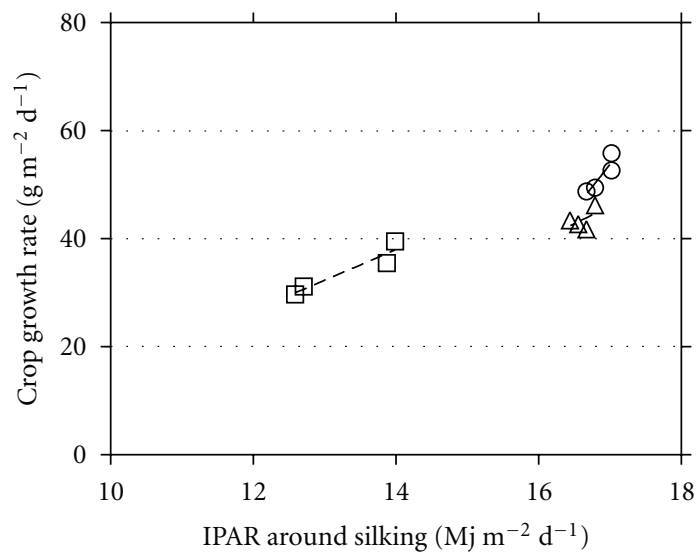

(d)

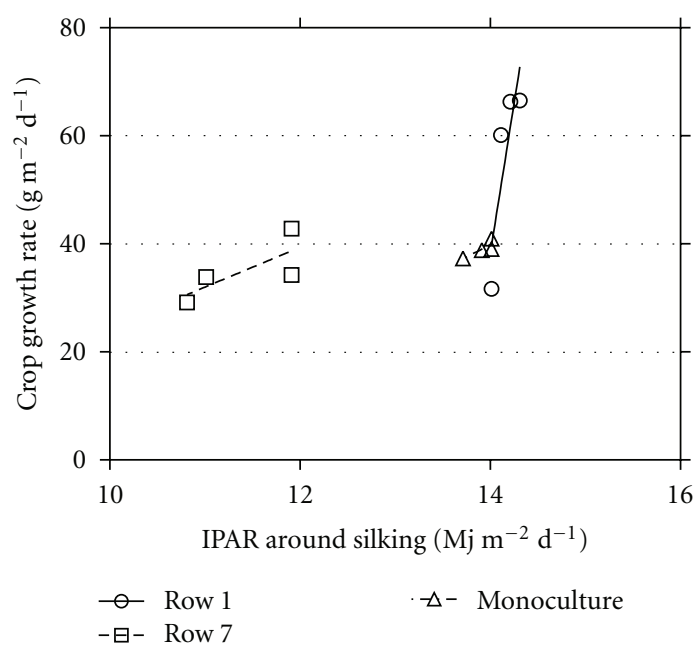

(f)

FIGURE 2: Corn growth rate around flowering related to IPAR in monocultures and in rows 1 (border) and 7 (center) in corn-soybeans MG III, during C1 (a), C2 (c), and C3 (e) and in corn-soybeans MG V, during C1 (b), C2 (d), and C3 (f).

However, total biomass versus IPAR during C1 (Figures 3(a) and 3(b)) was significantly lower than during C2 (Figures $3(\mathrm{c})$ and 3(d)) and C3 (Figures 3(e) and 3(f)).

High RUE is crucial to maximizing crop efficiency. In corn, RUE values ranged from 3 to $4 \mathrm{~g} \mathrm{MJ}^{-1}$. Although plants in row 1 accumulated higher biomass and yielded better, (Tables 1 and 2), RUE did not increase.

4.3. Grain Yield. Yields of corn plants located in the border rows of the corn strips (1 and 12) were higher than that 


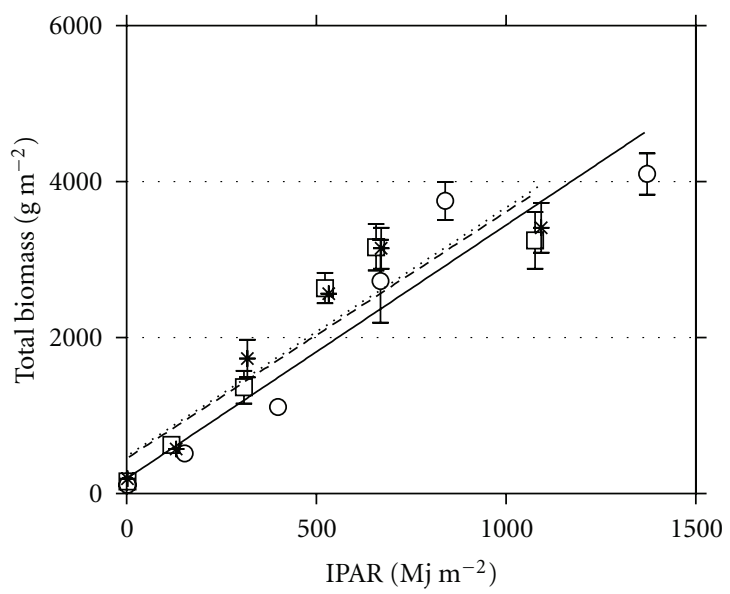

(a)

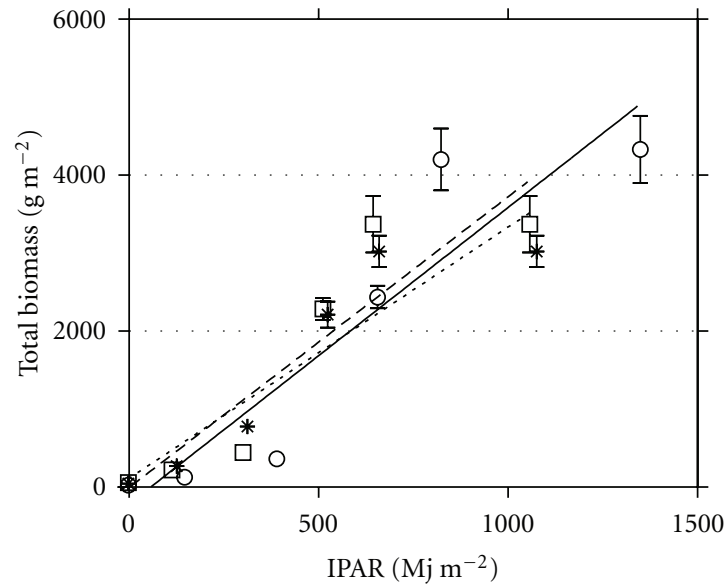

(c)

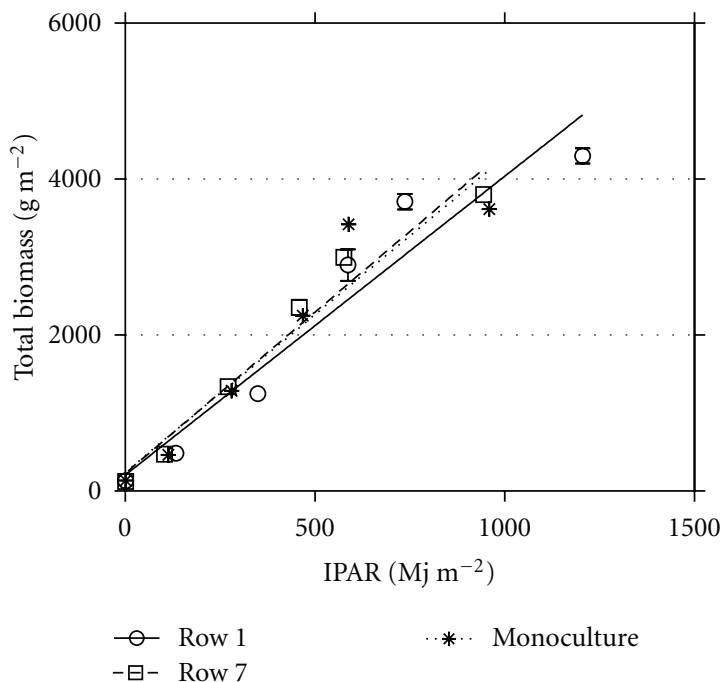

(e)

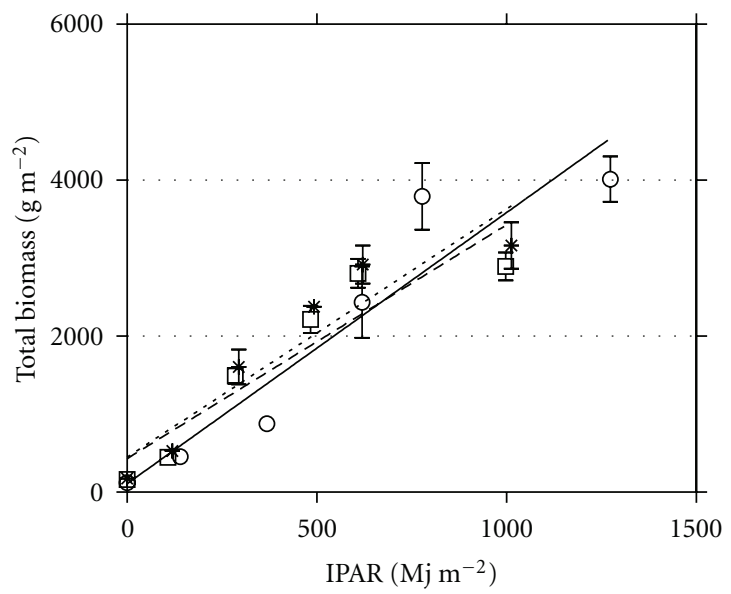

(b)

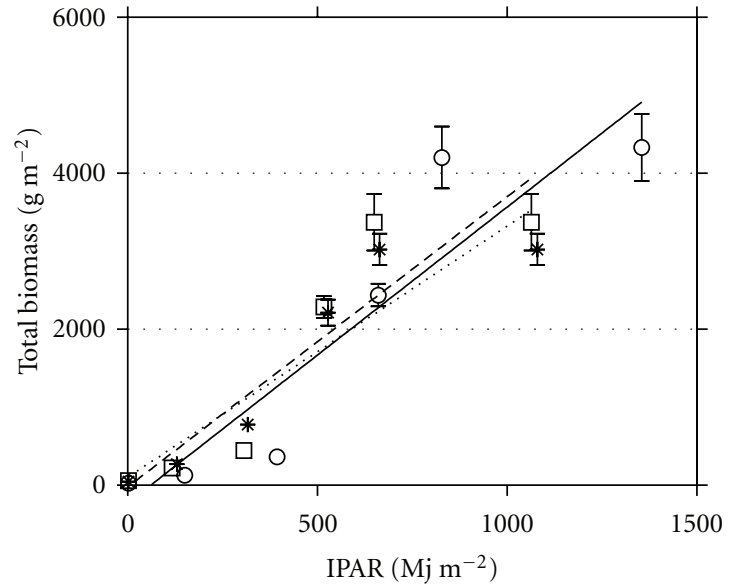

(d)

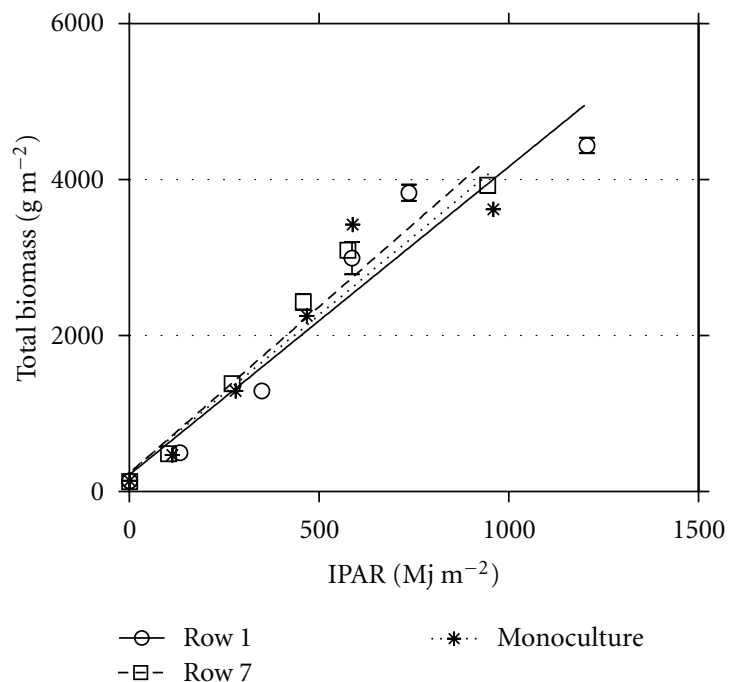

(f)

FIgURE 3: Total biomass versus IPAR in rows 1 (border) and 7 (center) in the strips and in monoculture, during C1 (a, b), C2 (c, d), and C3 (e, f). (a), (c), and (e) correspond to corn-soybeans MG III, and (b), (d), and (f) to corn-soybeans MG V. 


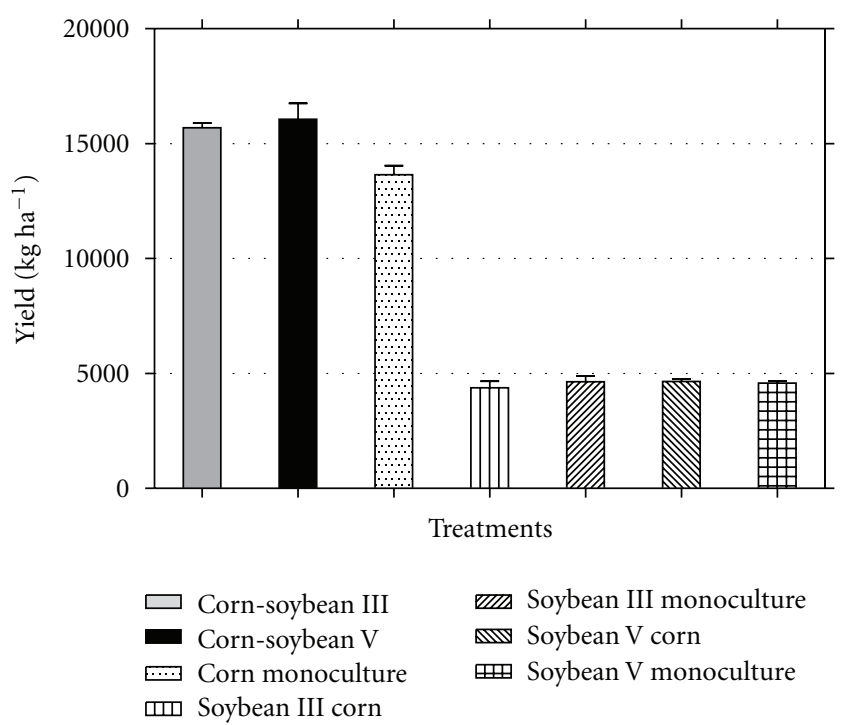

(a)

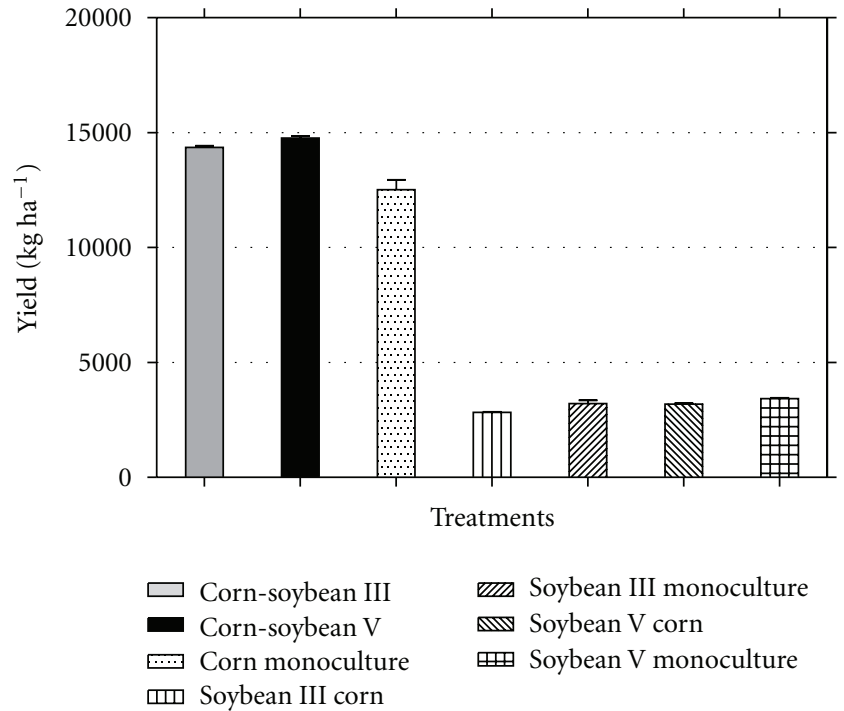

(b)

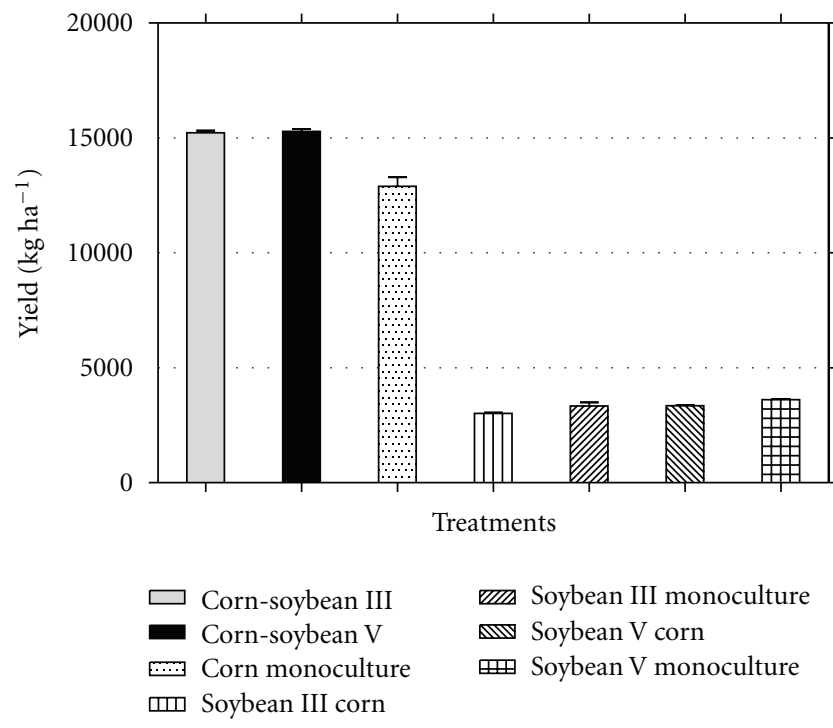

(c)

FIgURE 4: Crop yields in monocultures and in intercropped in C1 (a), C2 (b), and C3 (c).

of plants located in the inner rows (e.g., row 7) and plant located in the monoculture. This response was similar in each year with subtle variations depending on the accompanying soybean cultivar (Tables 1 and 2). Corn yield increased 13, 13 , and $16 \%$ when cultivated with MG III soybean strip and 15,15 , and $16 \%$ with MG V soybean strip, during C1, C2, and C3, respectively (Figure 4). Results are similar to that obtained in USA [15, 16], China [17], and Argentina, $[18,19]$.

4.4. Grain Yield Components. GNUA of plants located in border rows (1 and 12) of the strip was higher than those located in the central row or in the monoculture in both corn-soybeans associations (Table 1), except in $\mathrm{C} 1$ in cornsoybeans MG III. This response may be explained by findings of Lesoing and Francis $[20,21]$ who reported that yield and its components increase as radiation interception increases. On the other hand, Andrade et al. [7] and also Fisher and Palmer [22] have reported that irradiance reductions around the critical period may reduce the crop yields by $50 \%$, whereas filling reduction may reduce yields by $25 \%$. In the three seasons, the highest GNUA values were achieved in plants located in outer rows (1 and 12) with highest IPAR (Figure 5).

This response was observed in both corn-soybeans strips. Results may be explained by findings of Maddonni et al. [23] who reported that when IPAR decreases at R1, it may account for up to $58 \%$ of GNUA reductions.

GNUA is a function of the growth rate during the flowering period (Andrade et al. [7]). Plants of outer rows 


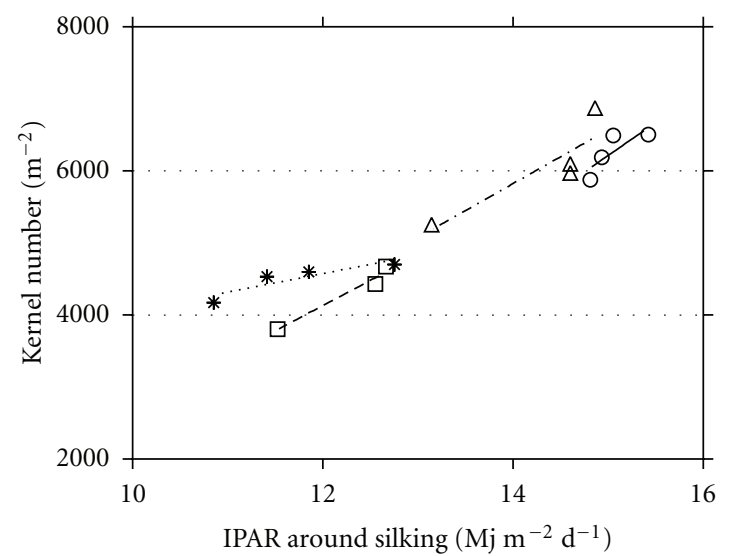

(a)

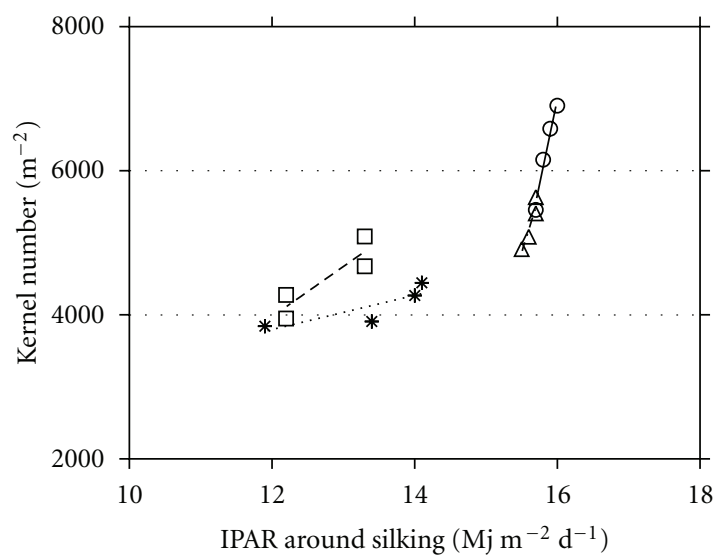

(c)

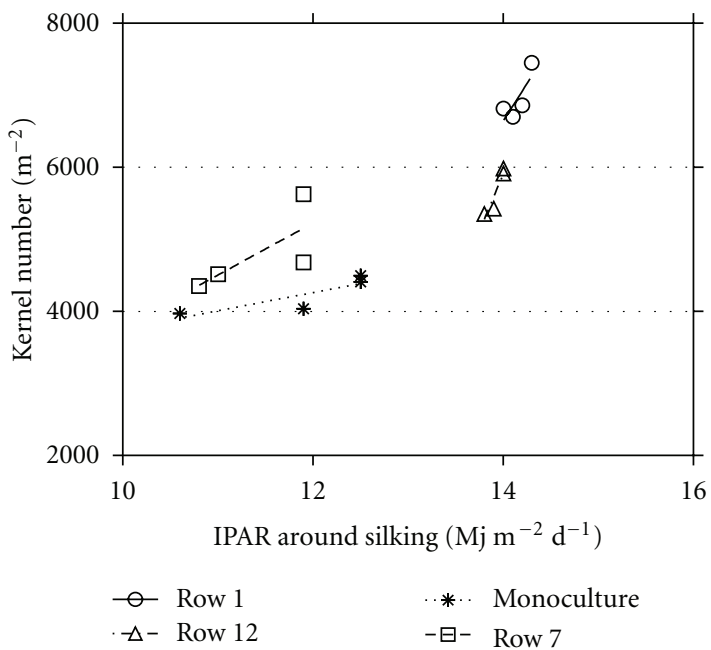

(e)

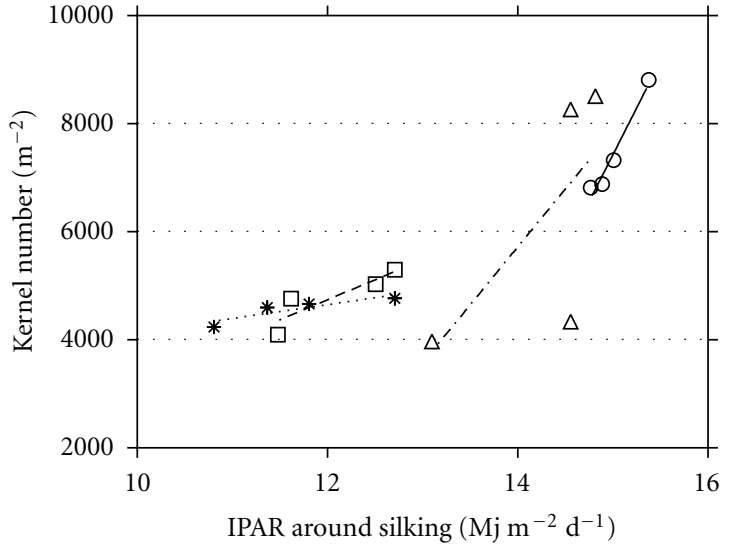

(b)

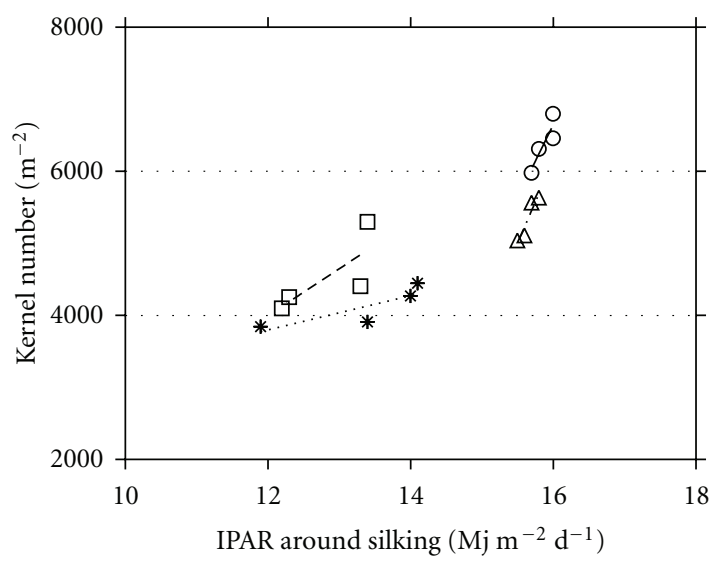

(d)

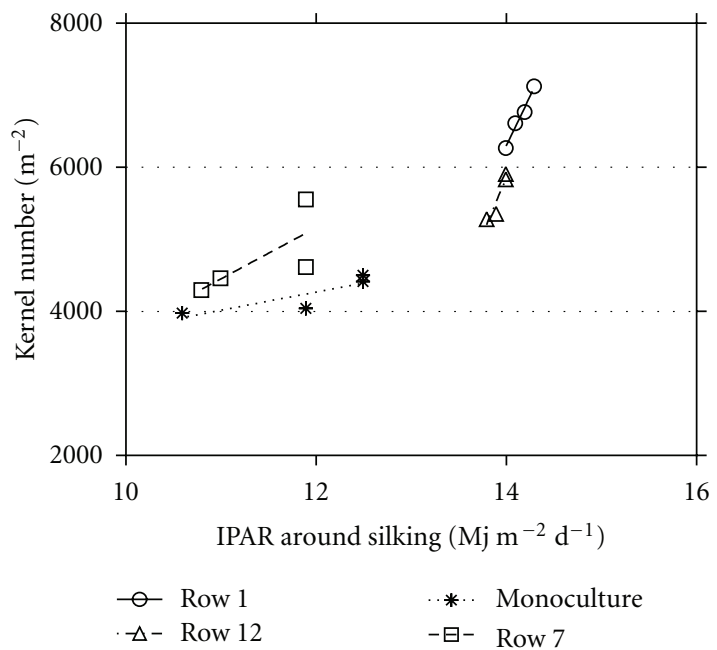

(f)

FIGURE 5: Number of corn grains per unit area in relation to IPAR around flowering in monoculture and in rows 1, 7, and 12 in corn-soybeans MG III strips, during C1 (a), C2 (c), and C3 (e) and in corn-soybeans MG V strips, during C1 (b), C2 (d), and C3 (f).

showed the highest CGR during the critical period, thus allowing a greater GNUA fixation. The decrease in the intercepted radiation was also correlated with the decrease in the GNUA, as has been found by Tollenaar et al. [24]; Kiniry and Knievel, [25]; Andrade et al. [5-7]; Maddonni et al. [23] in corn monocultures. The lesser response measured in C2 may be due to unfavorable water balance during crop cycle (Figure 6).

Both GNP and ENP showed similar tendencies, since plants of outer rows in the strip had higher values than those 


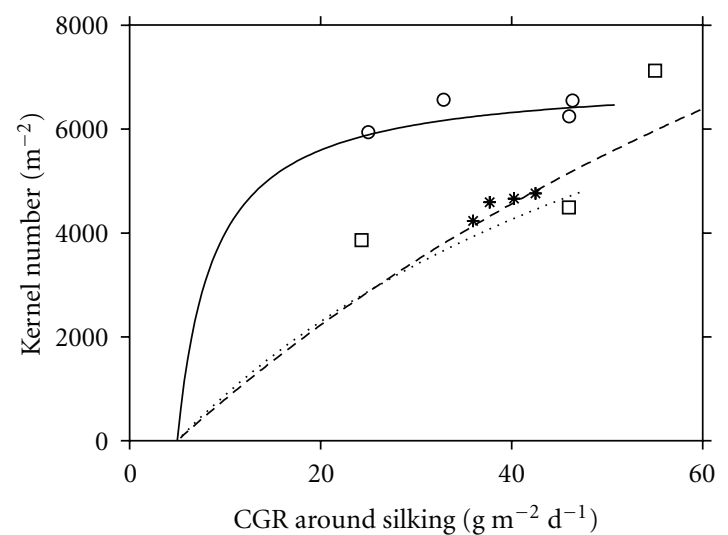

(a)

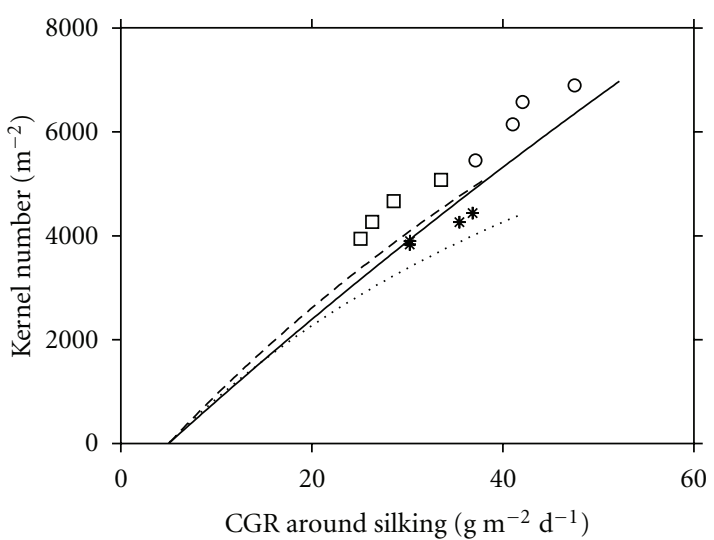

(c)

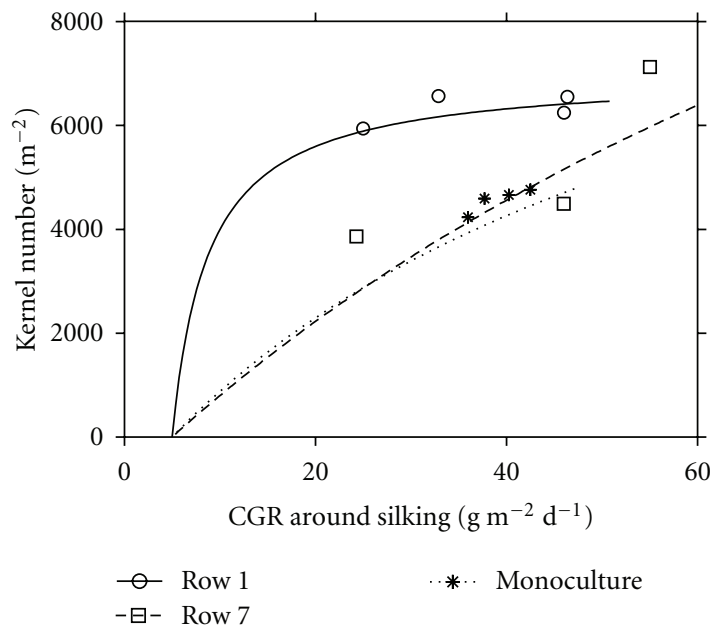

(e)

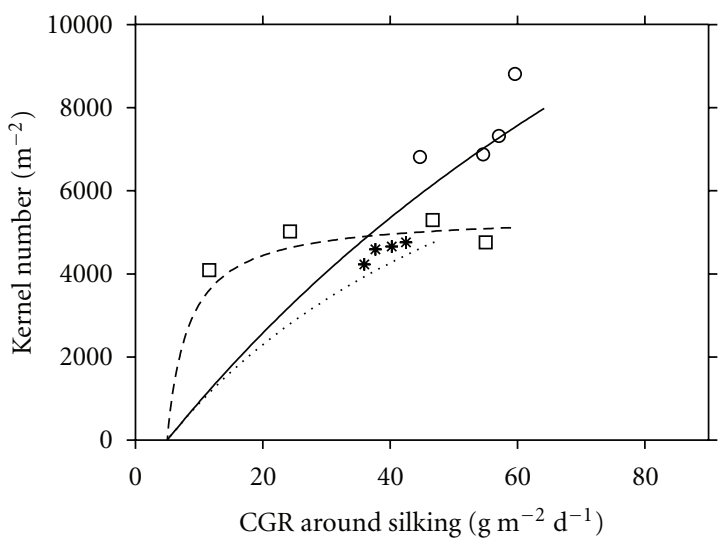

(b)

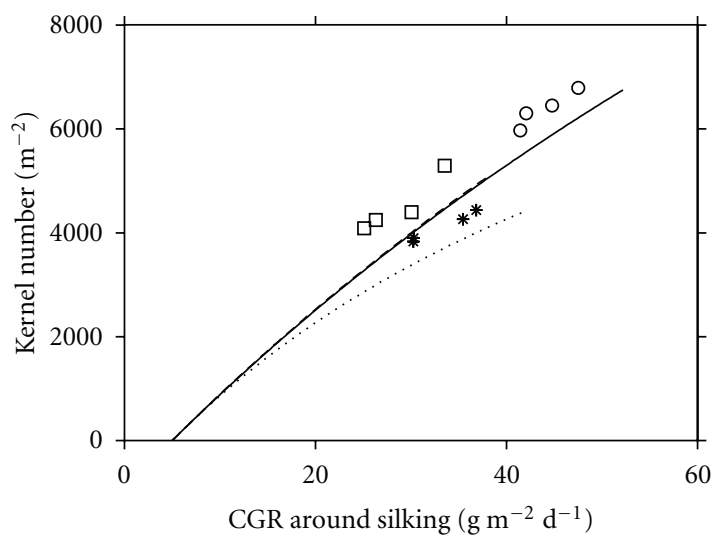

(d)

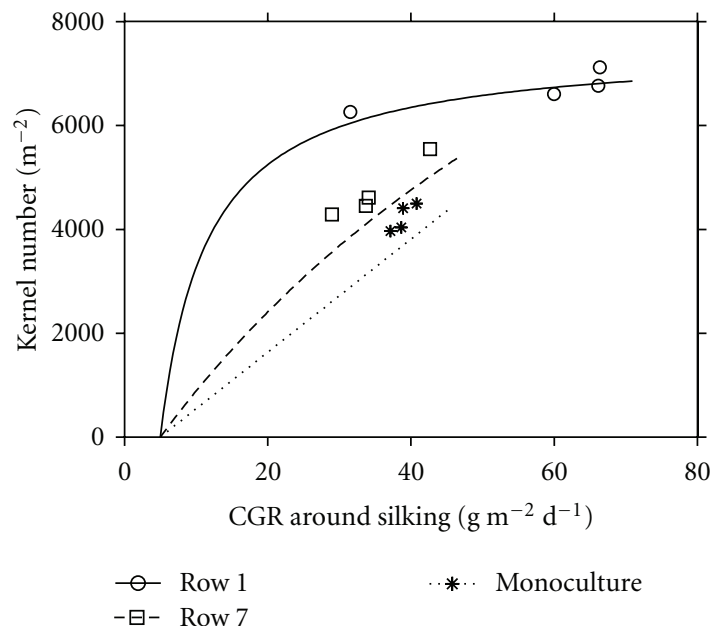

(f)

FIGURE 6: Number of corn grains per unit area in relation to crop growth rate around silking in the monoculture and in the strips 1 (border) and 7 (center) in corn-soybeans MG III strips, during C1 (a), C2 (c), and C3 (e), and of the corn-soybeans MG V strips, in C1 (b), C2 (d) and $\mathrm{C} 3$ (f).

of plants located in the center or in the monocultures. Plants of row 1 generated a second ear in $60 \%$ of the time of plants of row 1 and plants of row 12 generated a second ear $40 \%$ of the time (Table 3). Similar results were reported by Lesoing and Francis [20] and Ghaffarzadeh et al. [26].
As far as grain number per ear, which is related to ear size, there were no significant differences, as it has also been found by Lesoing and Francis [21] and Francis et al. [27]. A probable explanation to this response is that although water stress occurred in year C2, it may have not been significant 
TABLE 3: Corn and soybean grain yield components and grain yield in monocultures and intercropped, during C1, C2, and C3. Ear number per plant (ENP, $\left.\mathrm{n}^{\circ} \mathrm{pl}^{-1}\right)$, ear number per unit area $\left(\mathrm{ENUA}, \mathrm{n}^{\circ} \mathrm{m}^{-2}\right)$, pods number per plant $\left(\mathrm{PNP}, \mathrm{n}^{\circ} \mathrm{pl}^{-1}\right)$, pods per unit area $\left(\mathrm{PUA}, \mathrm{n}^{\circ} \mathrm{m}^{-2}\right)$, 1000 -grain weight $(1000 \mathrm{GW}, \mathrm{g})$, grain number per plant $\left(\mathrm{GNP}, \mathrm{n}^{\circ} \mathrm{pl}^{-1}\right)$, and GNUA $\left(\mathrm{n}^{\circ} \mathrm{m}^{-2}\right), \mathrm{GY}\left(\mathrm{kg} \mathrm{ha}^{-1}\right)$. Locations 1,7 , or 12 correspond to northern, central, and south rows, respectively. In the monoculture, the measurements were done at the center of the plot. Numbers in the same column followed by same letter are not significantly different $(P<0.05)$.

\begin{tabular}{|c|c|c|c|c|c|c|c|c|c|c|c|c|c|}
\hline \multirow{2}{*}{ Treatment } & \multirow{2}{*}{$\begin{array}{l}\text { Location } \\
\text { (rows) }\end{array}$} & \multicolumn{3}{|c|}{$\operatorname{ENP}\left(\mathrm{n}^{\circ} \mathrm{pl}^{-1}\right)$} & \multicolumn{3}{|c|}{ ENUA $\left(n^{\circ} m^{-2}\right)$} & \multicolumn{3}{|c|}{$\operatorname{PNP}\left(\mathrm{n}^{\circ} \mathrm{pl}^{-1}\right)$} & \multicolumn{3}{|c|}{$\operatorname{PUA}\left(\mathrm{n}^{\circ} \mathrm{m}^{-2}\right)$} \\
\hline & & $\mathrm{C} 1$ & $\mathrm{C} 2$ & $\mathrm{C} 3$ & $\mathrm{C} 1$ & $\mathrm{C} 2$ & $\mathrm{C} 3$ & $\mathrm{C} 1$ & $\mathrm{C} 2$ & $\mathrm{C} 3$ & $\mathrm{C} 1$ & $\mathrm{C} 2$ & $\mathrm{C} 3$ \\
\hline \multirow{3}{*}{ Strip corn/soybean III } & 1 & $1.5 \mathrm{a}$ & $1.6 \mathrm{a}$ & $1.6 \mathrm{a}$ & $12.6 \mathrm{a}$ & $14.8 \mathrm{a}$ & $14.8 \mathrm{a}$ & - & - & - & - & - & - \\
\hline & 7 & $1.2 \mathrm{a}$ & $1.2 \mathrm{~b}$ & $1.2 \mathrm{~b}$ & $9.8 \mathrm{a}$ & $9.8 \mathrm{bc}$ & $9.8 \mathrm{bc}$ & - & - & - & - & - & - \\
\hline & 12 & $1.6 \mathrm{a}$ & $1.6 \mathrm{a}$ & $1.6 \mathrm{a}$ & $13.4 \mathrm{a}$ & $13.4 \mathrm{ac}$ & $13.4 \mathrm{ac}$ & - & - & - & - & - & - \\
\hline \multirow{3}{*}{ Strip corn/soybean V } & 1 & $1.6 \mathrm{a}$ & $1.6 \mathrm{a}$ & $1.8 \mathrm{a}$ & $15 \mathrm{a}$ & $15 \mathrm{a}$ & $16 \mathrm{a}$ & - & - & - & - & - & - \\
\hline & 7 & $1.2 \mathrm{a}$ & $1.2 \mathrm{a}$ & $1.2 \mathrm{~b}$ & $10 \mathrm{~b}$ & $10 \mathrm{~b}$ & $10 \mathrm{~b}$ & - & - & - & - & - & - \\
\hline & 12 & $1.6 \mathrm{a}$ & $1.6 \mathrm{a}$ & $1.6 \mathrm{ab}$ & $14 \mathrm{ab}$ & $13 \mathrm{ab}$ & $14 \mathrm{ab}$ & - & - & - & - & - & - \\
\hline Corn monoculture & Center & $1.2 \mathrm{a}$ & $1.1 \mathrm{~b}$ & $1.1 \mathrm{~b}$ & $9.6 \mathrm{a}$ & $8.4 \mathrm{~b}$ & $8.4 \mathrm{~b}$ & - & - & - & - & - & - \\
\hline \multirow{3}{*}{ Strip soybean III/corn } & 1 & - & - & - & - & - & - & $22 d$ & $20 \mathrm{~d}$ & $24 d$ & $777 d$ & $898 \mathrm{~d}$ & $648 \mathrm{~d}$ \\
\hline & 7 & - & - & - & - & - & - & $39 \mathrm{e}$ & $37 \mathrm{e}$ & $38 \mathrm{~d}$ & $1541 d$ & $1360 \mathrm{e}$ & $1438 \mathrm{~d}$ \\
\hline & 12 & - & - & - & - & - & - & $30 \mathrm{ab}$ & $26 \mathrm{ab}$ & $28 \mathrm{a}$ & $988 d$ & 872 de & $922 d$ \\
\hline $\begin{array}{l}\text { Soybean III } \\
\text { monoculture }\end{array}$ & Center & - & - & - & - & - & - & $37 \mathrm{e}$ & $34 \mathrm{e}$ & $35 \mathrm{~d}$ & $1478 \mathrm{~d}$ & 1304de & $1379 d$ \\
\hline \multirow{3}{*}{ Strip soybean V/corn } & 1 & - & - & - & - & - & - & $25 d$ & $24 a$ & $28 \mathrm{a}$ & $1041 d$ & $924 d$ & $975 d$ \\
\hline & 7 & - & - & - & - & - & - & $35 \mathrm{de}$ & $33 \mathrm{ab}$ & $34 \mathrm{ab}$ & $1387 d$ & $1231 d$ & $1299 \mathrm{~d}$ \\
\hline & 12 & - & - & - & - & - & - & $30 \mathrm{de}$ & $27 \mathrm{ab}$ & $28 \mathrm{ab}$ & $1446 \mathrm{~d}$ & $1284 d$ & $1354 \mathrm{~d}$ \\
\hline $\begin{array}{l}\text { Soybean } \mathrm{V} \\
\text { monoculture }\end{array}$ & Center & - & - & - & - & - & - & $44 \mathrm{e}$ & $41 \mathrm{e}$ & $42 \mathrm{e}$ & $1808 \mathrm{~d}$ & $1605 d$ & $1694 d$ \\
\hline \multirow{2}{*}{ Treatment } & \multirow{2}{*}{$\begin{array}{l}\text { Locatio } \\
\text { (rows) }\end{array}$} & \multicolumn{3}{|c|}{$1000 \mathrm{GW}(\mathrm{g})$} & \multicolumn{3}{|c|}{$\operatorname{GNP}\left(\mathrm{n}^{\circ} \mathrm{pl}^{-1}\right)$} & \multicolumn{3}{|c|}{ GNUA $\left(n^{\circ} m^{-2}\right)$} & \multicolumn{3}{|c|}{ GY $\left(\mathrm{kg} \mathrm{ha}^{-1}\right)$} \\
\hline & & $\mathrm{C} 1$ & $\mathrm{C} 2$ & $\mathrm{C} 3$ & $\mathrm{C} 1$ & $\mathrm{C} 2$ & $\mathrm{C} 3$ & $\mathrm{C} 1$ & $\mathrm{C} 2$ & $\mathrm{C} 3$ & $\mathrm{C} 1$ & $\mathrm{C} 2$ & $\mathrm{C} 3$ \\
\hline \multirow{3}{*}{ Strip corn soybean III } & 1 & $308 \mathrm{a}$ & $316 a$ & $312 \mathrm{a}$ & $474 \mathrm{a}$ & $677 \mathrm{a}$ & $699 b$ & $6325 a$ & $6267 \mathrm{a}$ & $6956 a$ & $19456 a$ & $19754 a$ & $21669 a$ \\
\hline & 7 & $292 \mathrm{a}$ & $297 \mathrm{a}$ & $294 \mathrm{a}$ & $487 \mathrm{a}$ & $628 \mathrm{a}$ & $555 \mathrm{ab}$ & $5052 b$ & $4488 b$ & $4792 b c$ & $14495 b$ & $13258 b$ & $13975 b$ \\
\hline & 12 & $323 a$ & $330 \mathrm{a}$ & $325 a$ & $425 \mathrm{a}$ & $649 a$ & $640 \mathrm{a}$ & $6108 \mathrm{ac}$ & $5252 c$ & $5667 \mathrm{c}$ & $19646 a$ & $17267 \mathrm{a}$ & $18385 c$ \\
\hline \multirow{3}{*}{ Strip corn soybean V } & 1 & $317 \mathrm{a}$ & $328 \mathrm{a}$ & $324 a$ & $799 b$ & $686 a b$ & $719 b$ & $7454 a$ & $6377 \mathrm{a}$ & $6686 a$ & $23546 a$ & $20916 a$ & $21669 a$ \\
\hline & 7 & $307 a$ & $301 \mathrm{a}$ & $298 \mathrm{a}$ & $554 \mathrm{ab}$ & $531 \mathrm{a}$ & $524 \mathrm{bc}$ & $4792 b$ & $4505 b$ & $4724 b$ & $14750 \mathrm{~b}$ & $13490 b$ & $13975 b$ \\
\hline & 12 & $315 a$ & $334 a$ & $330 a$ & $694 \mathrm{ab}$ & 639ab & $646 \mathrm{ab}$ & $6264 a$ & $5328 b$ & $5587 \mathrm{~b}$ & $19454 a$ & $17746 c$ & $18385 c$ \\
\hline Corn monoculture & Center & $299 a$ & $305 a$ & $301 \mathrm{a}$ & $514 \mathrm{a}$ & $554 a$ & $519 a$ & $4561 c$ & $4108 c$ & $4288 c$ & $13636 b$ & $12520 \mathrm{~b}$ & $12898 \mathrm{~b}$ \\
\hline \multirow{3}{*}{ Strip soybean III corn } & 1 & $172 b$ & $165 b$ & $167 b$ & - & - & - & $1850 \mathrm{~d}$ & $1400 \mathrm{~d}$ & $1440 \mathrm{~d}$ & $3169 d$ & $2314 d$ & $2406 \mathrm{~d}$ \\
\hline & 7 & $170 \mathrm{~b}$ & $166 \mathrm{~b}$ & $168 b$ & - & - & - & $2940 d$ & $1800 \mathrm{ef}$ & 1860de & $5013 d$ & $2994 \mathrm{e}$ & $3116 \mathrm{e}$ \\
\hline & 12 & $170 \mathrm{~b}$ & $168 b$ & $163 b$ & - & - & - & $2110 \mathrm{~d}$ & $1600 \mathrm{df}$ & 1720de & $3583 d$ & $2678 \mathrm{f}$ & $2788 \mathrm{f}$ \\
\hline $\begin{array}{l}\text { Soybean III } \\
\text { monoculture }\end{array}$ & Center & $162 b$ & $160 \mathrm{~b}$ & $167 b$ & - & - & - & $2870 \mathrm{~d}$ & $2010 \mathrm{e}$ & $2010 \mathrm{e}$ & $4633 d$ & $3205 e$ & $3336 \mathrm{e}$ \\
\hline \multirow{3}{*}{ Strip soybean V corn } & 1 & $172 b$ & $165 b$ & $167 b$ & - & - & - & $2130 \mathrm{~d}$ & $1410 \mathrm{~d}$ & 1440d & $3655 d$ & $2317 d$ & $2412 \mathrm{~d}$ \\
\hline & 7 & $170 \mathrm{~b}$ & $166 \mathrm{~b}$ & $168 b$ & - & - & - & $2550 d$ & $2170 \mathrm{e}$ & $2260 \mathrm{e}$ & $4312 d$ & $4312 \mathrm{e}$ & $3793 e$ \\
\hline & 12 & $170 \mathrm{~b}$ & $168 b$ & $163 b$ & - & - & - & $2300 \mathrm{~d}$ & 1640de & 1770de & $3905 d$ & $3905 f$ & $2897 f$ \\
\hline $\begin{array}{l}\text { Soybean V } \\
\text { monoculture }\end{array}$ & Center & $162 b$ & $160 \mathrm{~b}$ & $167 b$ & - & - & - & $2820 \mathrm{~d}$ & $2150 \mathrm{e}$ & $2180 \mathrm{e}$ & $4566 \mathrm{~d}$ & $4566 \mathrm{e}$ & $3612 \mathrm{e}$ \\
\hline
\end{tabular}

during the grain filling period. Previous experiments report contrasting responses on the water stress on this yield component $[20,21,26,28,29]$. It is important to note that two weeks following crop blooming, the young grain does not accumulate dry weight. Instead, a great mitotic activity occurs, responsible for determining the number of cells of the endosperms and also the starch granules [30].
Unfavorable conditions during this stage not only reduce the endospermatic cells, but also the number of starch granules, thereby affecting the grain size potential $[31,32]$. After the above-mentioned stage, grain growth is linear and increases up to $90 \%$ of final weight. At this stage the grain weight gain is linearly positively correlated to air temperature $[33,34]$. 


\section{Soybeans}

5.1. Irradiance. The IPAR in row 1 was significantly lower than those in the central and twelfth rows and also than those in the monocultures. Reduced IPAR values were evident once the corn plants in the adjacent rows surpassed stage V6 (70 cm height). The shading effect extended its influence to the three nearest consecutive rows of soybeans. The radiation received in the further soybean rows was not affected by the corn strip (Table 1).

5.2. IPAR and CGR. The highest IPAR levels were registered in the central row of the strip and also in the center of the monoculture. This high IPAR allowed the highest CGR in all cases. In soybeans MG III-corn, IPAR was $10 \mathrm{Mj} \mathrm{m}^{-2} \mathrm{~d}^{-1}$ and CGR 20 was $\mathrm{g} \mathrm{m}^{-2} \mathrm{~d}^{-1}$, during C1 and C3, and $15 \mathrm{~g} \mathrm{~m}^{-2} \mathrm{~d}^{-1}$, during C2. Within row 7 and also in the monoculture IPAR approached $14 \mathrm{Mjm}^{-2} \mathrm{~d}^{-1}$ and CGR ranged from 20 to $60 \mathrm{~g} \mathrm{~m}^{-2} \mathrm{~d}^{-1}$, in $\mathrm{C} 1$ and $\mathrm{C} 3$, and from 15 to $25 \mathrm{~g} \mathrm{~m}^{-2} \mathrm{~d}^{-1}$, in C2 (Figure 7). The responses in soybeans MG V-corn followed the same tendency: highest IPAR levels approached $14 \mathrm{Mj} \mathrm{m}^{-2} \mathrm{~d}^{-1}$ and CGR surpassed $50 \mathrm{~g} \mathrm{~m}^{-2} \mathrm{~d}^{-1}$.

5.3. RUE. RUE in soybeans ranged from 0.5 to $1.2 \mathrm{~g} \mathrm{Mj}^{-1}$ in the three seasons. Differences were detected in the strip plots as compared to that in the monocultures (Table 2, Figure 8).

5.4. Grain Yield. During C1, there were no differences in between yield between any row in either of the maturity groups. During C2 and C3, in both soybean cultivars, yields in rows 1 and 12 significantly differed to row 7 and to monoculture (Table 3).

Average yields of soybean strips MG III were 6, 13, and $11 \%$ lower than those in the monoculture, whereas in MG V yields were 2, 8 , and $8 \%$ lower than those in the monocultures during C1, C2, and C3, respectively (Figure 4). Results are similar to those obtained by Pendleton et al. [35], Lesoing and Francis, [20, 21], West and Griffith, [15], Ghaffarzadeh et al. [16], and Francis et al. [27].

5.5. Grain Yield Components. GNUA was significantly lower in plants located in rows 1 and 12, as compared to that of the plants located in the central row and those in the monoculture. This response was almost identical in both soybean cultivars (Table 3 ).

A possible explanation of this response may be found by looking at the reduction in IPAR and in CGR of plants located in rows 1 and 12 during the critical period. Figure 9 shows the positive relationship among the GN and IPAR: in almost the entire crop growth cycle, row 1 had lower GN, probably due to a lower IPAR accumulation, due to the shade caused by the nearby corn plants.

On the other hand, plants in row 12 had lower GN. Since shading effect occurred because the corn was located on the southern side of the strip, any explanation is available for this result. GN values of plants in the central row were similar to those of row 12 . Overall responses observed, however, are in close coincidence to those determined by Fehr and Caviness [36] who proposed a positive relationship among GN and accumulated IPAR from R3 to R6. Thus, the longer the duration of this critical period, the increased IPAR [13].

The enhanced IPAR allowed an increased CGR, which may have contributed to the increase in GNUA in plants located in row 7 and also in the monoculture, as compared to that in row 1 . Observed responses were similar in both maturity groups (Figure 10).

GNUA was higher in MG V than in MG III. Since resource overlapping is a major issue when searching for the explanations in the performance of two species [37], (Table 3), a possible explanation of different responses may be found by looking at their critical periods (R3-R6, [36]). The critical period for MG may have been less overlapped with corn's critical period than MG III.

PNP and PUA were significantly lower in the plants located in rows 1 and 12 as compared to those of plants located in the center of the strip and also to that in the monocultures (Table 3). As for corn, any statistical differences were found in GW (Table 3).

\section{Conclusions}

Corn plants increased their yield in border rows when grown next to soybeans. Increased yield was closely correlated to increased radiation interception which allowed an increased crop growth rate around the critical period (R1), thus increasing dry matter partition to the grains. The increased IPAR in plants of border rows, associated to an increased CGR, also boosted the differentiation of greater number of ears and consequently greater grain number per plant. These yield subcomponents explained the increased number of grains per unit area.

In soybeans, there were no clear advantages when grown next to corn. Those plants growing in the borders next to corn plants reduced their yield compared to those of the monocultures, however only significantly in MG III. The yield component closely associated to yield reduction was GNUA.

Our experiments contribute to the explanation of the observed increased corn yields and the limited penalties of soybean genotypes grown in strips. The increased availability of new corn and soybean genetically modified genotypes, coupled to new herbicides and machinery technologies, may allow expanding this crop technique to broader areas and/or to different crop sequences and/or crop associations. If yield components affected are more closely identified, every single actual crop production system may be improved by selecting more appropriate genotypes to be used in strip intercropping, thus contributing to the sustainability of our agricultural systems. 


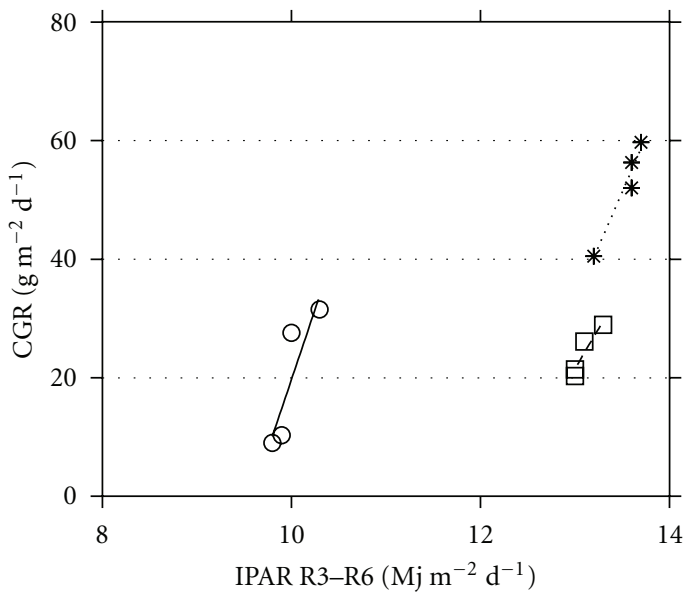

(a)

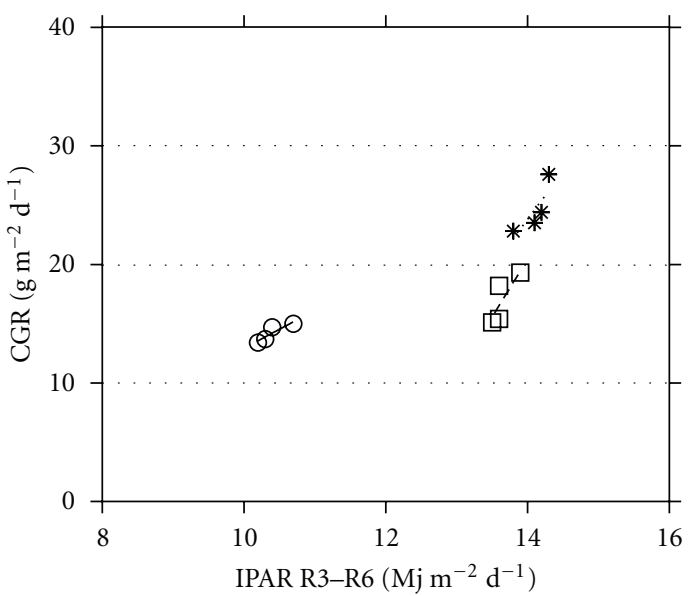

(c)

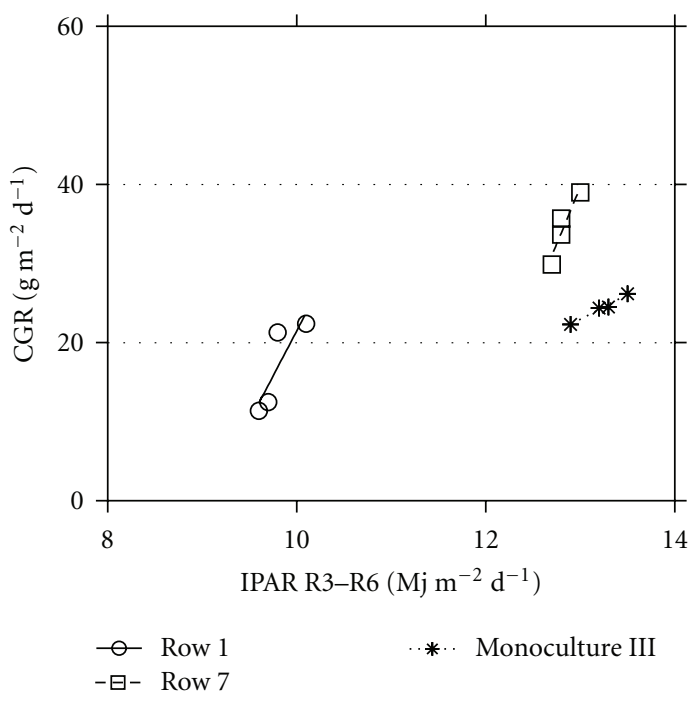

(e)

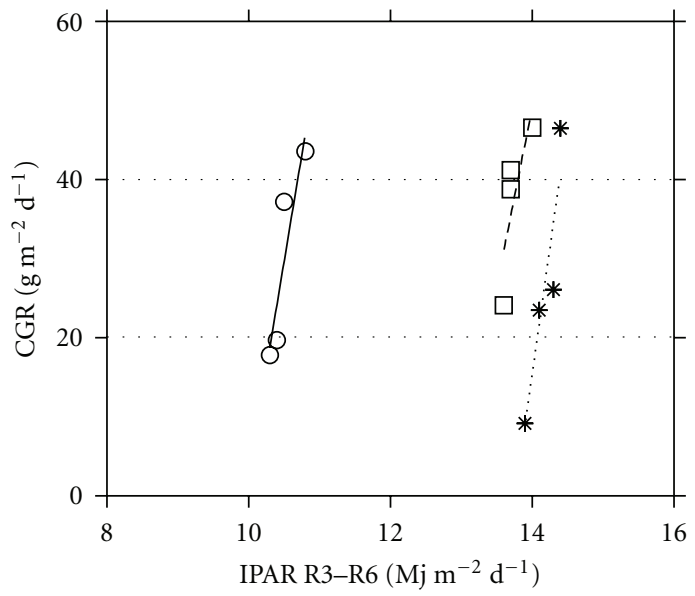

(b)

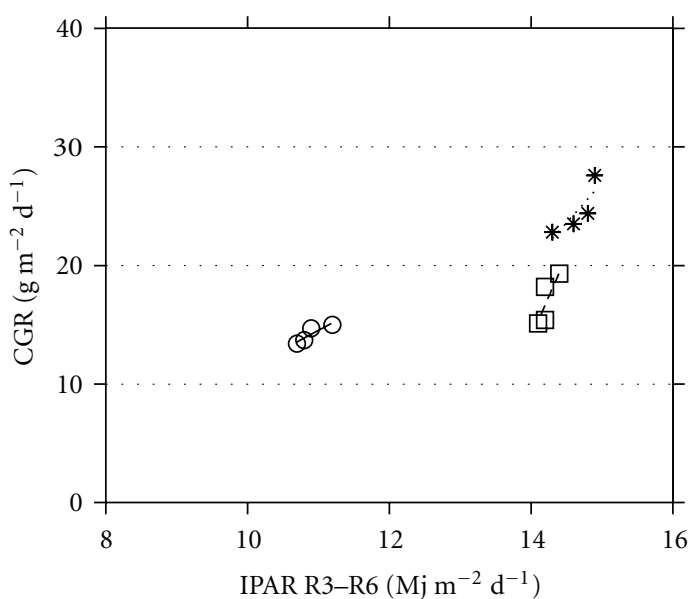

(d)

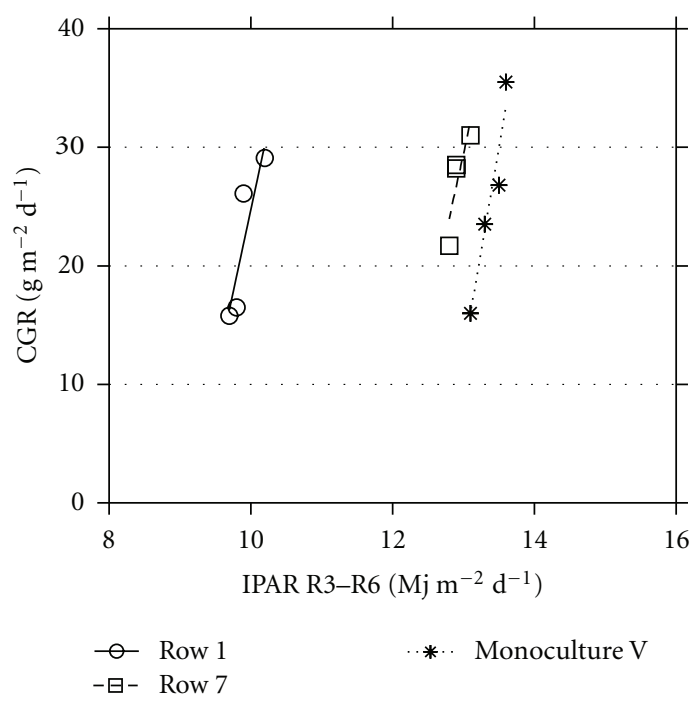

(f)

FIgURE 7: CGR within the period R3-R6 as a function of IPAR in the monoculture and in rows 1 and 7 of soybeans MG III-corn strips, during C1 (a), C2 (c), and C3 (e) and of soybeans MG V-corn strips, during C1 (b), C2 (d), and C3 (f). 


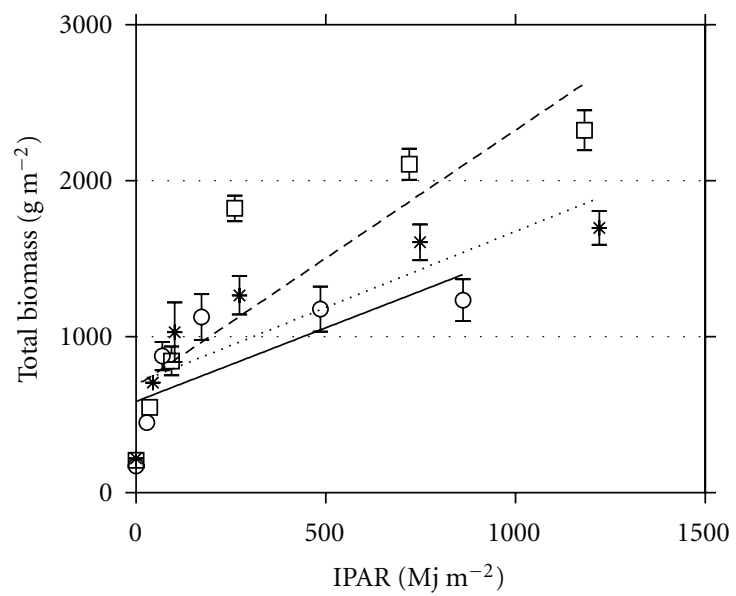

(a)

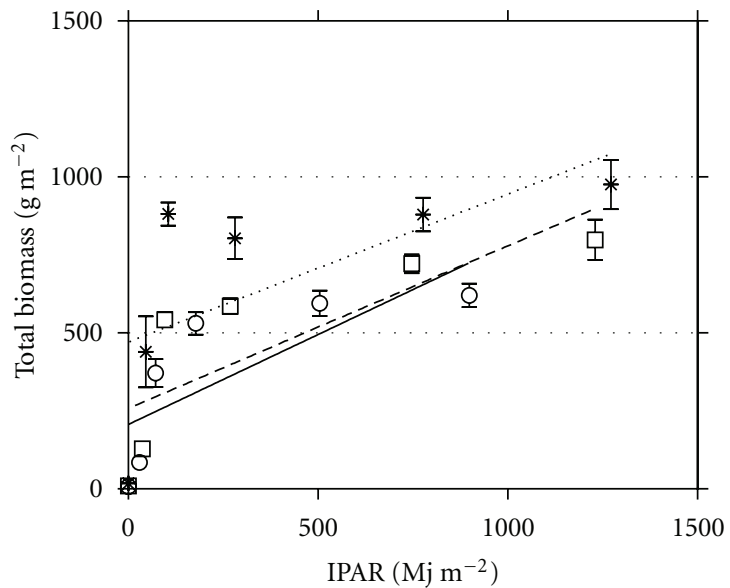

(c)

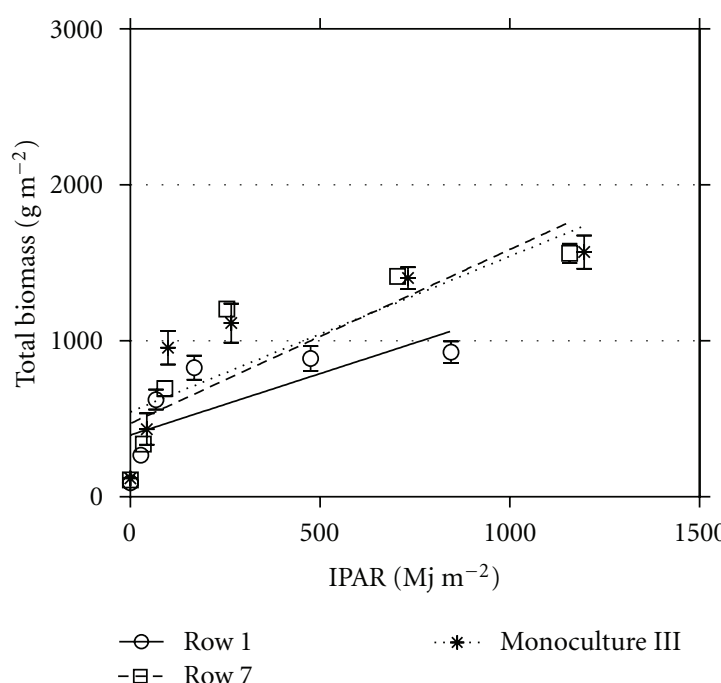

(e)

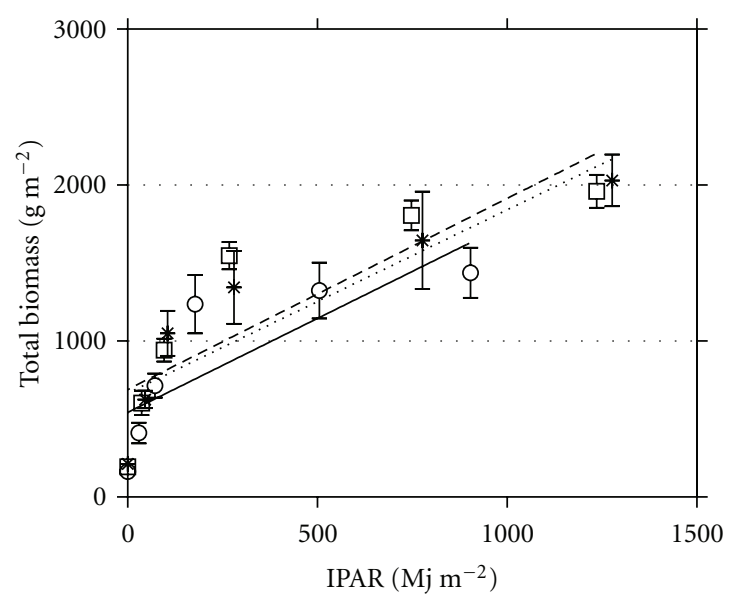

(b)

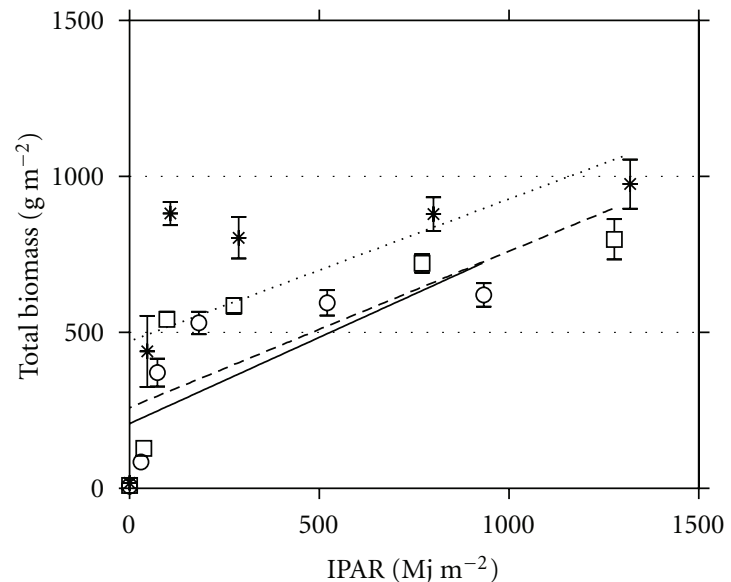

(d)

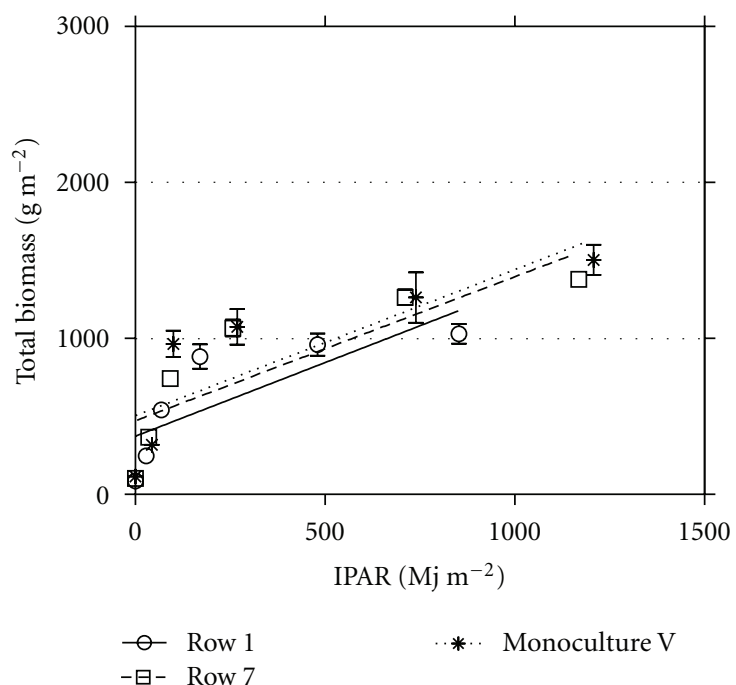

(f)

Figure 8: Total biomass versus IPAR in rows 1 and 7 of strips and in the monoculture, during C1 (a) and (b), C2 (c) and (d) and C3 (e) and (f). (a), (c), and (e) correspond to soybeans MG III, and (b), (d), and (f) to corn-soybeans MG V. 


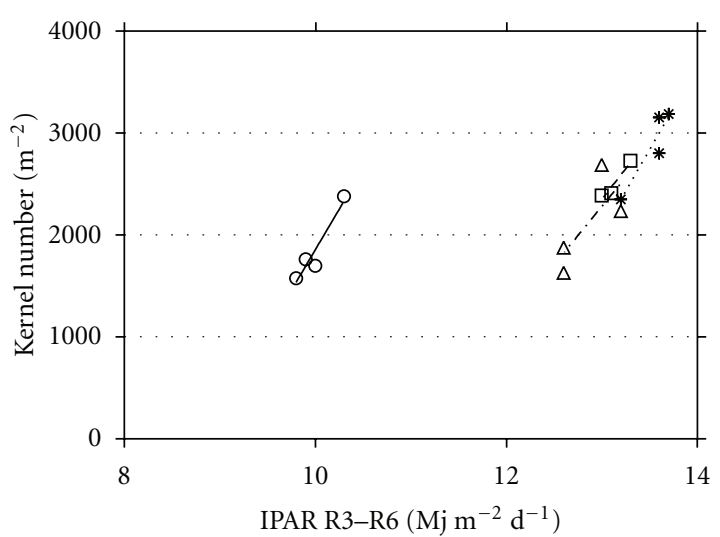

(a)

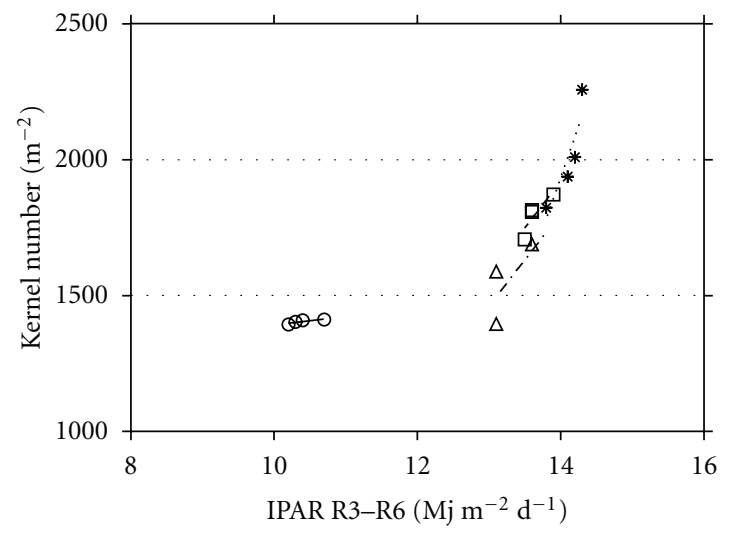

(c)

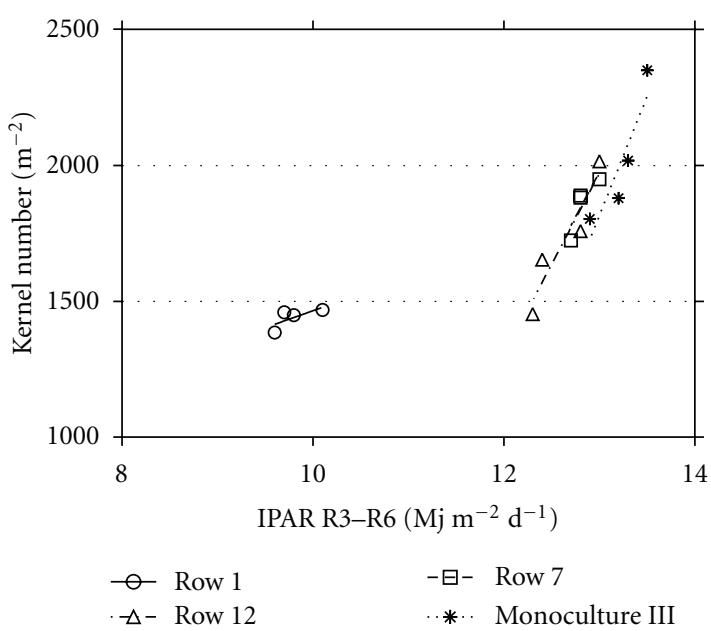

(e)

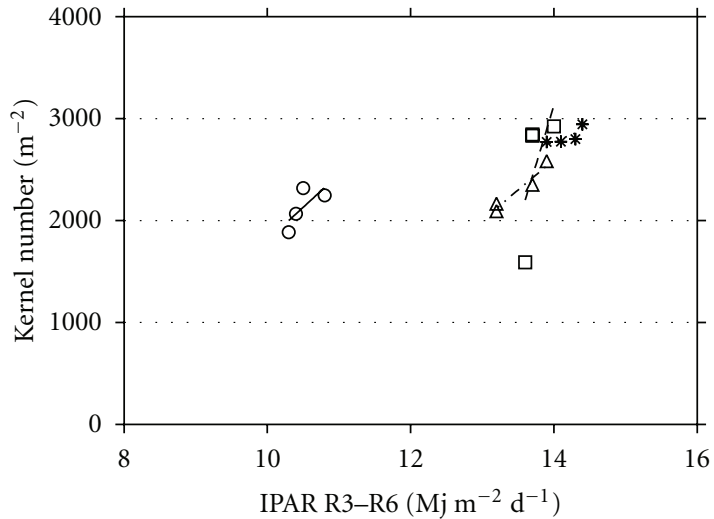

(b)

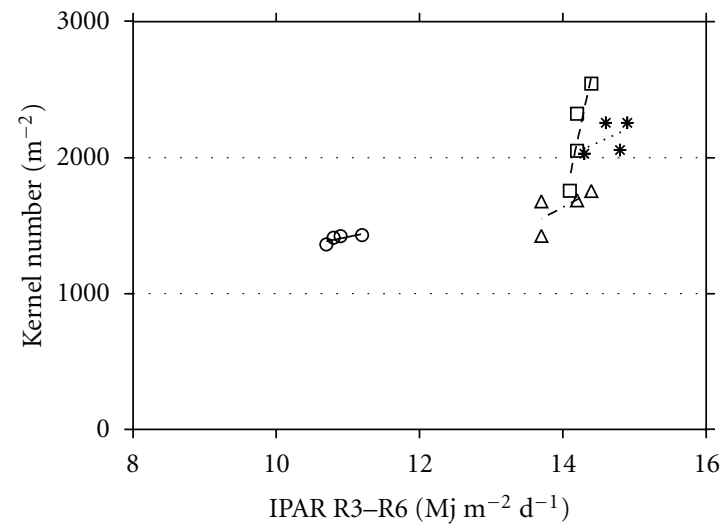

(d)

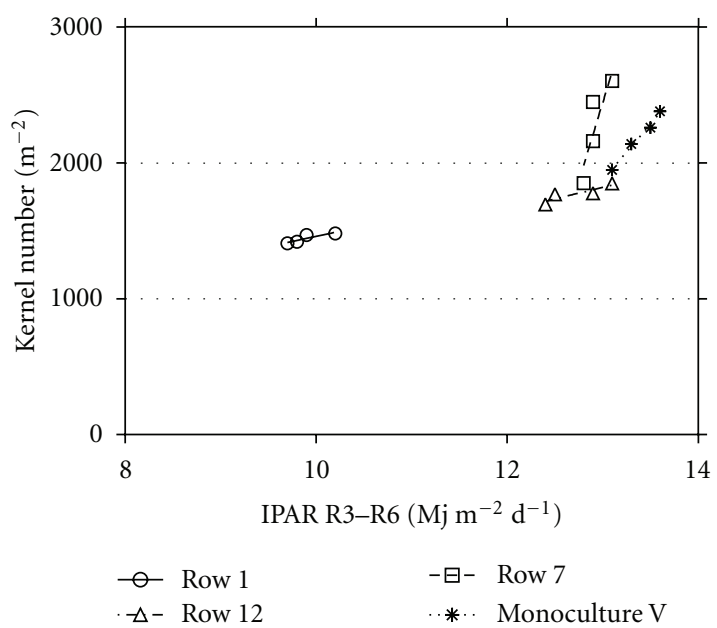

(f)

FIGURE 9: GNUA in relation to IPAR within R3-R6 in monocultures and in the strips in row 1, 7 and 12 of soybeans MG III-corn strips during C1 (a), C2 (c), and C3 (e) and in soybeans MG V strips during C1 (b), C2 (d), and C3 (f).

\section{Acknowledgments}

Technical expertise of J. R. Pérez for collecting and processing plant data is gratefully recognized. The willingness of the owner of the farm, Mr. G. Verdelli, where experiments were done, is also fully appreciated. Experiments were partially funded by several technical services made to agrichemical companies and are part of the research project of ESL. Suggestions and corrections made by referees and editor are gratefully acknowledged. 


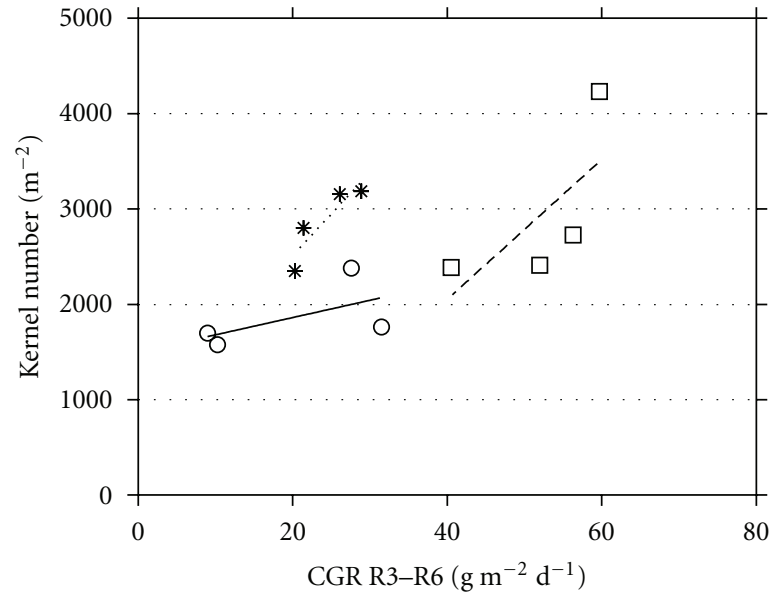

(a)

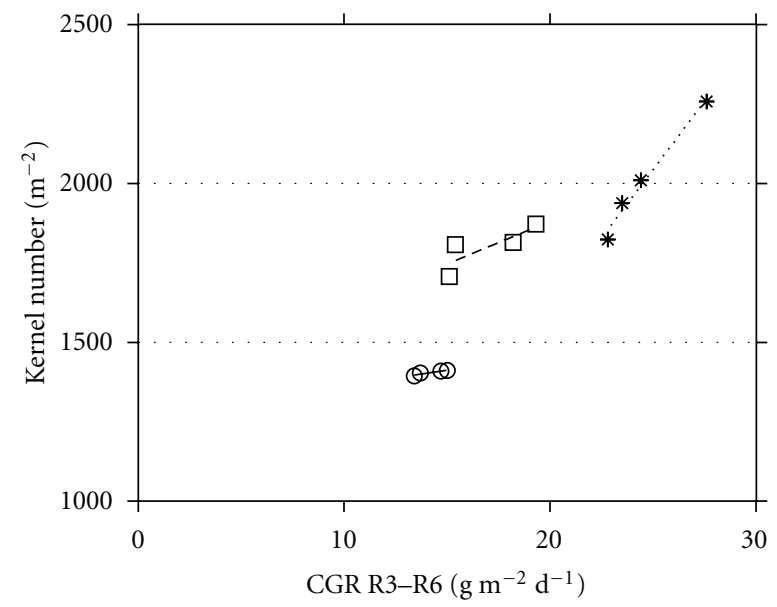

(c)

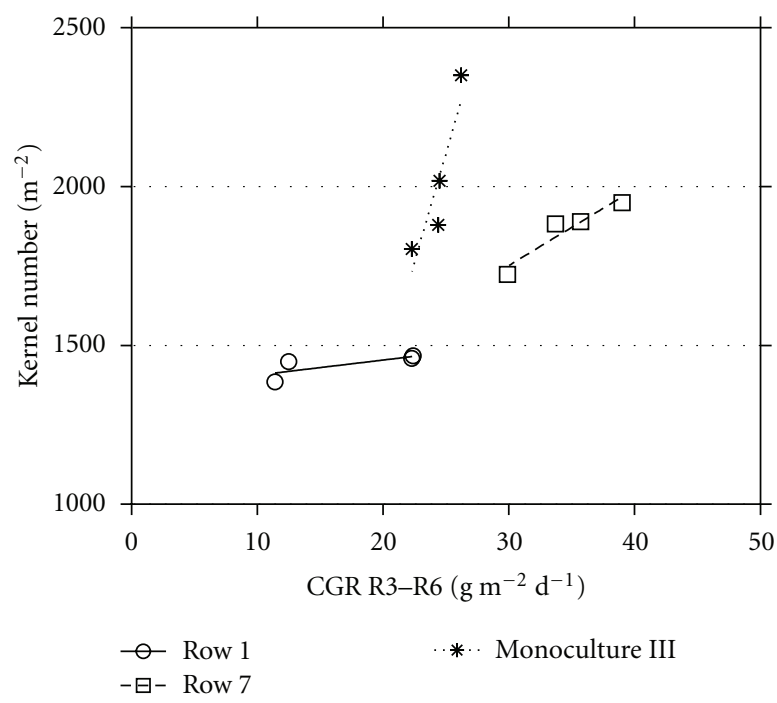

(e)

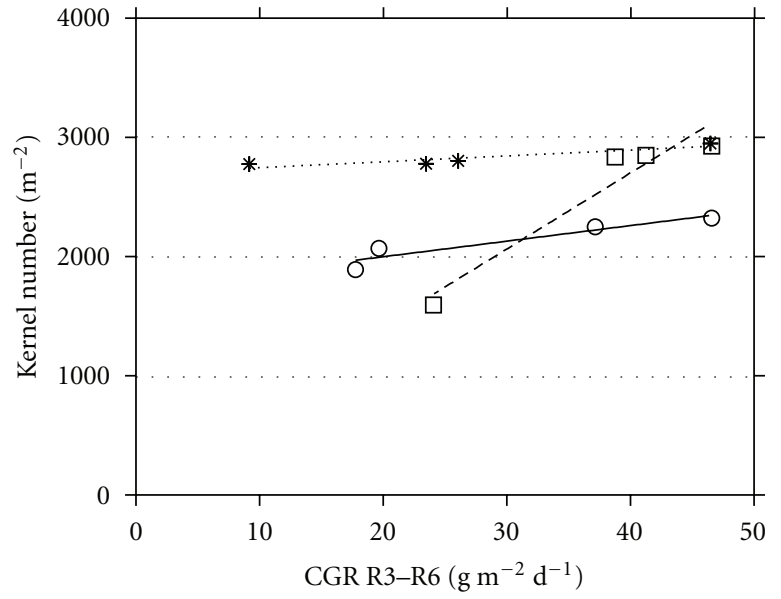

(b)

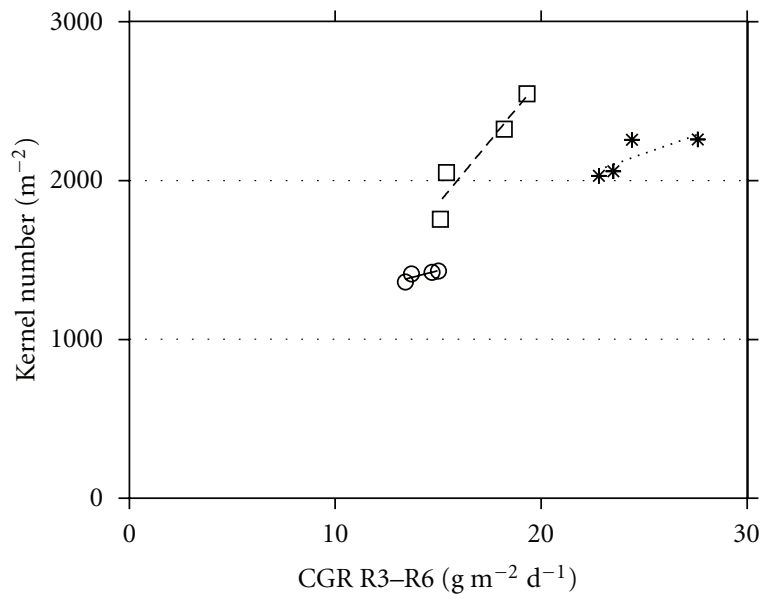

(d)

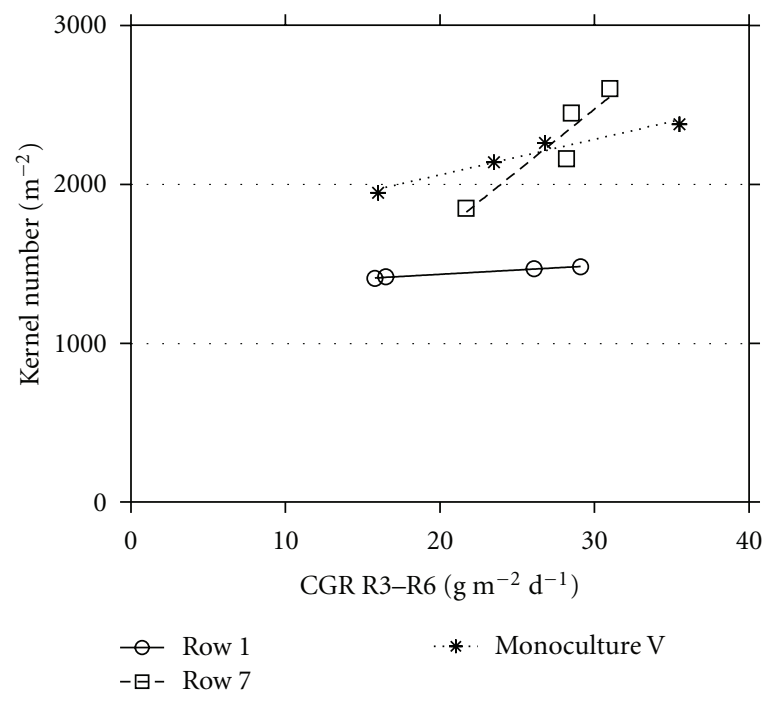

(f)

FIGURE 10: GNUA related to CGR within R3-R6 in monoculture and in the rows 1 and 7 (center) of soybeans MG III-corn strips during C1 (a), C2 (c), and C3 (e) and in soybeans MG V-corn strips during C1 (b), C2 (d), and C3 (f). 


\section{References}

[1] D. Tilman, "Niche tradeoffs, neutrality, and community structure: a stochastic theory of resource competition, invasion, and community assembly," Proceedings of the National Academy of Sciences of the United States of America, vol. 101, no. 30, pp. 10854-10861, 2004.

[2] S. Kantor, Intercropping, Cooperative Extension Washington State University King County, Washington, DC, USA, 1999.

[3] D. J. Andrews and A. H. Kassam, "Importance of multiple cropping in increasing world food supplies," in Multiple Cropping, R. I. Papendick, A. Sanchez, and G. B. Triplett, Eds., vol. 27, pp. 1-10, ASA (American Society of Agronomy), Madison, Wis, USA, 1976.

[4] L. Temón, O. Valentinuz, and S. Cabada, Variaciones en el Peso de Granos y Número de Granos en Híbridos de Maíz Frente a Cambios en la Disponibilidad de Nitrógeno, Actualización técnica maíz, girasol y sorgo. INTA Paraná, Entre Ríos Province, Argentina, 2006.

[5] F. H. Andrade, C. Vega, S. Uhart, A. Cirilo, M. Cantarero, and O. Valentinuz, "Kernel number determination in maize," Crop Science, vol. 39, no. 2, pp. 453-459, 1999.

[6] F. H. Andrade, A. Cirilo, S. Uhart, and M. E. Otegui, Ecofisiología del Cultivo de Maíz, Dekalb press, Buenos Aires, Argentina, 1996.

[7] F. H. Andrade, L. A. N. Aguirrezábal, and R. H. Rizzalli, "Crecimiento y rendimiento comparados," in Bases para el Manejo del Maíz, el Girasol y la Soja, F. H. Andrade and V. O. Sadras, Eds., pp. 61-96, INTA-Universidad de Mar del Plata, Balcarce, Argentina, 2000.

[8] A. G. Kantolic, P. I. Jiménez, and E. B. de la Fuente, "Ciclo ontogénico, dinámica del desarrollo y generación del rendimiento y la calidad en soja," in Producción de Granos. Bases Funcionales para su Manejo, Fauba, Ed., pp. 167-201, Universidad de Buenos Aires, Buenos Aires, Argentina, 2003.

[9] Anónimo, "Carta de suelos de la República Argentina," Hoja 3363-17, INTA, Marcos Juárez, Argentina, 1978.

[10] K. P. Gallo, C. S. T. Daughtry, and C. L. Wiegand, "Errors in measuring absorbed radiation and computing crop radiation use efficiency," Agronomy Journal, vol. 85, no. 6, pp. 1222$1228,1993$.

[11] J. L. Lindquist, T. J. Arkebauer, D. T. Walters, K. G. Cassman, and A. Dobermann, "Maize radiation use efficiency under optimal growth conditions," Agronomy Journal, vol. 97, no. 1, pp. 72-78, 2005.

[12] R. Hunt, D. R. Causton, B. Shipley, and A. P. Askew, "A modern tool for classical plant growth analysis," Annals of Botany, vol. 90, no. 4, pp. 485-488, 2002.

[13] A. G. Kantolic and E. H. Satorre, "Elementos centrales de ecofisiología del cultivo de soja," in Manual Práctico para la Producción de Soja, D. Z. Duarte, Ed., pp. 19-37, Hemisferio Sur, Buenos Aires, Argentina, 2004.

[14] M. Tollenaar and W. Migus, "Dry matter accumulation of maize grown hydrioponically under controlled-environment and field conditions," Canadian Journal of Plant Science, vol. 64, pp. 475-485, 1984.

[15] T. D. West and D. R. Griffith, "Effect of strip intercropping corn and soybean on yield and profit," Journal of Production Agriculture, vol. 5, pp. 107-110, 1992.

[16] M. Ghaffarzadeh, F. G. Prechac, and R. M. Cruse, "Grain yield response of corn, soybean, and oat grown in a strip intercropping system," American Journal of Alternative Agriculture, vol. 9, no. 4, pp. 171-177, 1994.
[17] L. Li, J. Sun, F. Zhang, X. Li, S. Yang, and Z. Rengel, "Wheat/maize or wheat/soybean strip intercropping I. Yield advantage and interspecific interactions on nutrients," Field Crops Research, vol. 71, no. 2, pp. 123-137, 2001.

[18] J. P. Monzón, T. J. Carrozza, P. Calviño, and F. H. Andrade, Efectos del Intercultivo en Franjas de Maíz y Soja Sobre el Rendimiento, Actas del Congreso Nacional del Maíz, Buenos Aires, Argentina, 2005.

[19] M. G. Díaz, W. Kuttel, R. Lopez, O. Caviglia, H. Peltzer, and E. Blanzaco, Evaluación de Diferentes Proporciones de MaízSoja en Intercultivo en Surcos, INTA-EA Paraná FCA (UNER), Buenos Aires, Argentina, 2008.

[20] G. W. Lesoing and C. A. Francis, "Strip intercropping effects on yield and yield components of corn, grain sorghum, and soybean," Agronomy Journal, vol. 91, no. 5, pp. 807-813, 1999.

[21] G. W. Lesoing and C. A. Francis, "Strip intercropping of grain sorghum/soybean in irrigated and rainfed environments," Journal of Production Agriculture, vol. 12, no. 4, pp. 601-606, 1999.

[22] K. S. Fischer and A. F. E. Palmer, "Tropical corn," in The Physiology of Tropical Field Crops, P. R. Goldsworthy and N. M. Fisher, Eds., pp. 213-248, John Wiley \& Sons, New York, NY, USA, 1984.

[23] G. A. Maddonni, A. G. Cirilo, and M. E. Otegui, "Row width and maize grain yield," Agronomy Journal, vol. 98, no. 6, pp. 1532-1543, 2006.

[24] M. Tollenaar, L. M. Dwyer, and D. W. Stewart, "Ear and kernel formation in corn hybrids representing three decades of grain yield improvement in Ontario," Crop Science, vol. 32, pp. 432438, 1992.

[25] J. R. Kiniry and D. P. Knievel, "Response of maize seed number to solar radiation intercepted soon after anthesis," Agronomy Journal, vol. 87, no. 2, pp. 228-234, 1995.

[26] M. Ghaffarzadeh, F. García Préchac, and R. M. Cruse, “Tillage effect on soil water content and corn yield in a strip intercropping system," Agronomy Journal, vol. 89, no. 6, pp. 893-899, 1997.

[27] C. A. Francis, C. A. Flor, and M. Prager, "Effects of bean association on yields and yield components of maize," Crop Science, vol. 18, pp. 760-764, 1978.

[28] M. G. Thwala and E. M. Ossom, "Legume-corn association influences crop characteristics and yields," http://www .cropscience.org.au/icsc2004/poster/2/1/2/1959_0ssomen.htm? print $=1.07 / 07 / 06$, verified July 2010, 2004.

[29] R. W. Willey and D. S. O. Osiru, "Studies on mixtures of corn and beans (Phaseolus vulgaris) with particular reference to plant population," Journal of Agricultural Science, vol. 79, pp. 519-529, 1972.

[30] V. H. Reddy and T. B. Daynard, "Endosperm characteristics associated with rate of grain filling and kernel size in corn," Maydica, vol. 28, pp. 339-355, 1983.

[31] N. M. Frey, "Dry matter accumulation in kernels of corn," Crop Science, vol. 21, pp. 118-122, 1981.

[32] R. J. Jones, J. A. Roessler, and S. Ouattar, "Thermal environment during endosperm cell division in corn: effects on number of endosperm cells and starch granules," Crop Science, vol. 25, pp. 830-834, 1985.

[33] A. G. Cirilo and F. H. Andrade, "Sowing date and kernel weight in maize," Crop Science, vol. 36, no. 2, pp. 325-331, 1996.

[34] M. Tollenaar and T. W. Bruulsema, "Efficiency of corn dry matter production during periods of complete leaf area expansion," Agronomy Journal, vol. 80, pp. 580-585, 1988. 
[35] J. W. Pendleton, C. D. Bolen, and R. D. Seif, "Alternating strips of corn and soybeans vs. solid plantings," Agronomy Journal, vol. 55, pp. 293-295, 1963.

[36] W. R. Fehr and C. E. Caviness, "Stages of soybean development," Special Report 80, Iowa State University, Ames, Iowa, USA, 1977.

[37] J. H. Vandermeer, The Ecology of Intercropping, Cambridge University Press, Cambridge, NY, USA, 1989. 


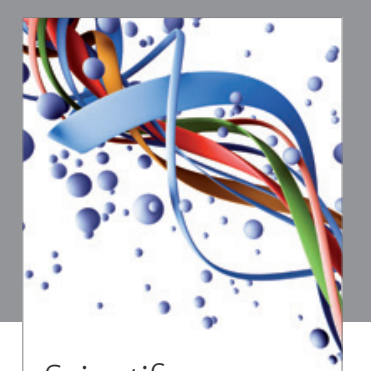

Scientifica
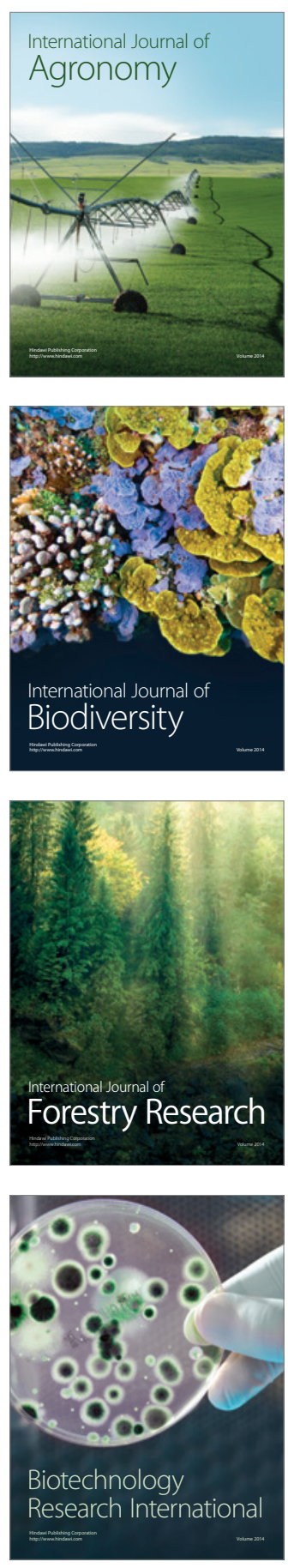
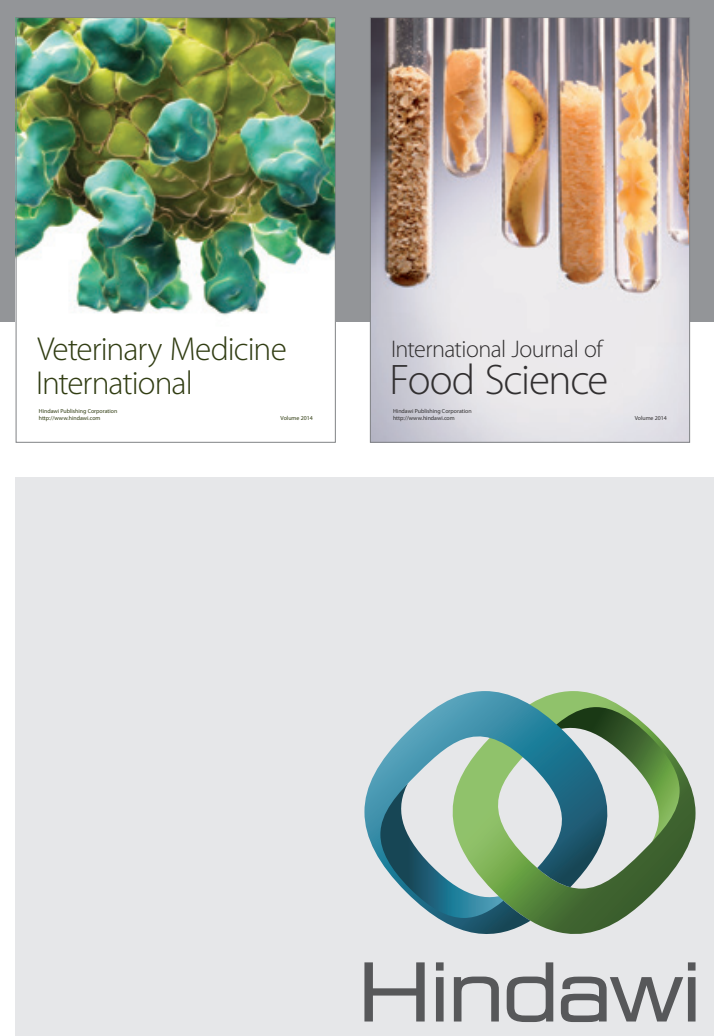

Submit your manuscripts at

http://www.hindawi.com
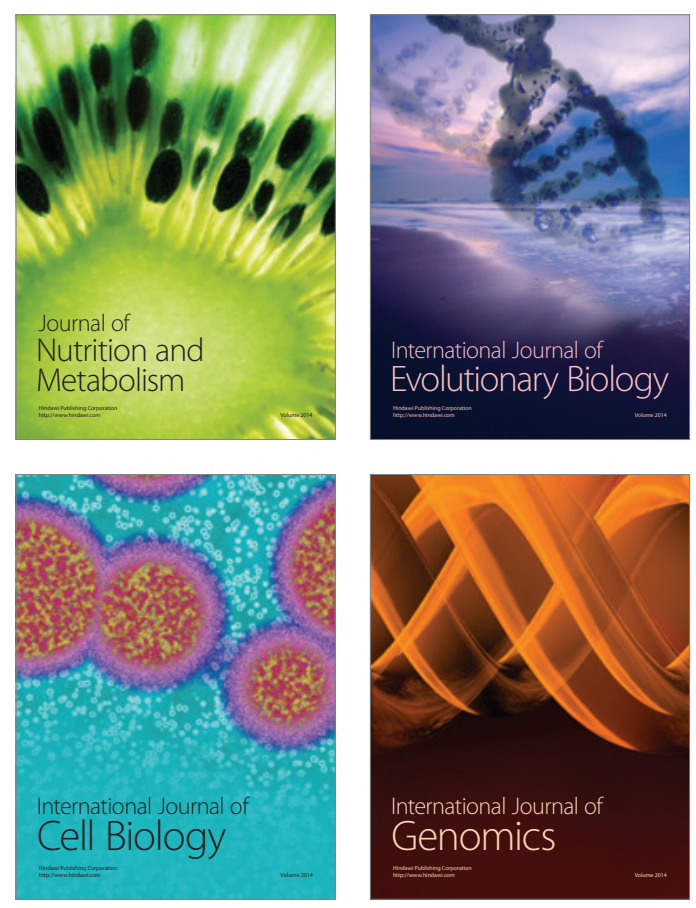
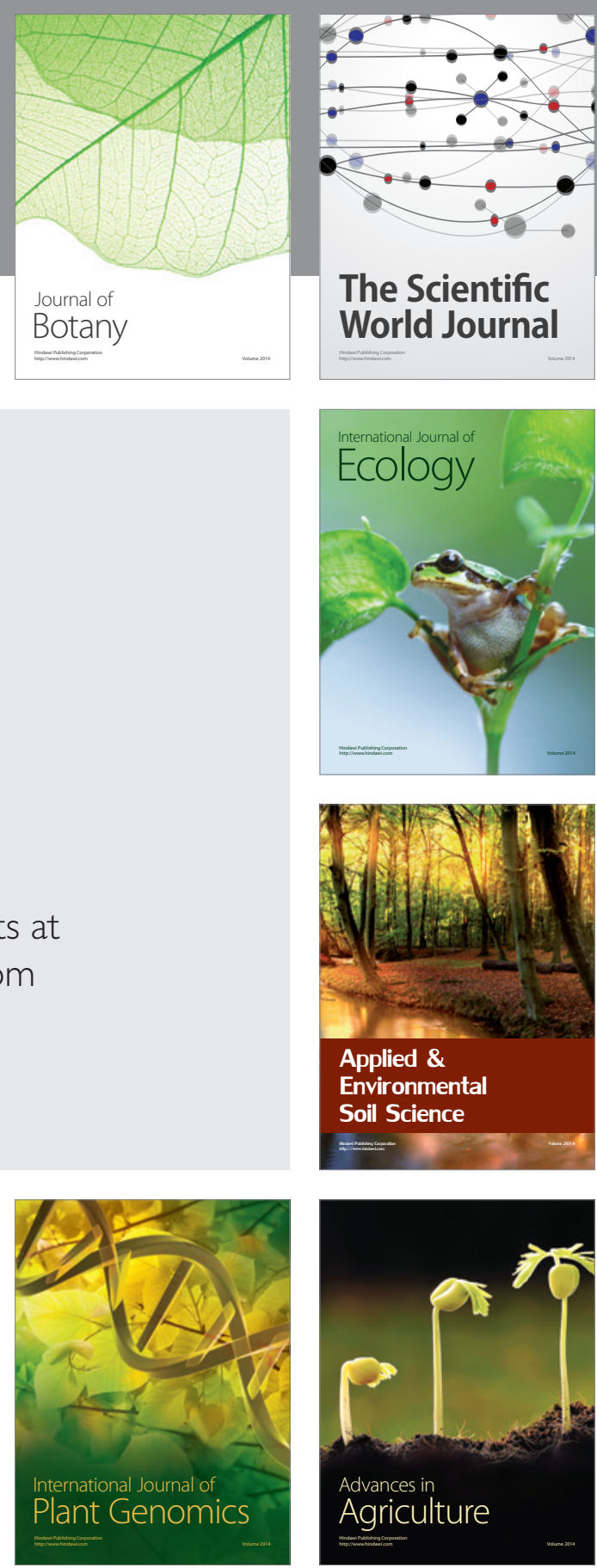

The Scientific World Journal
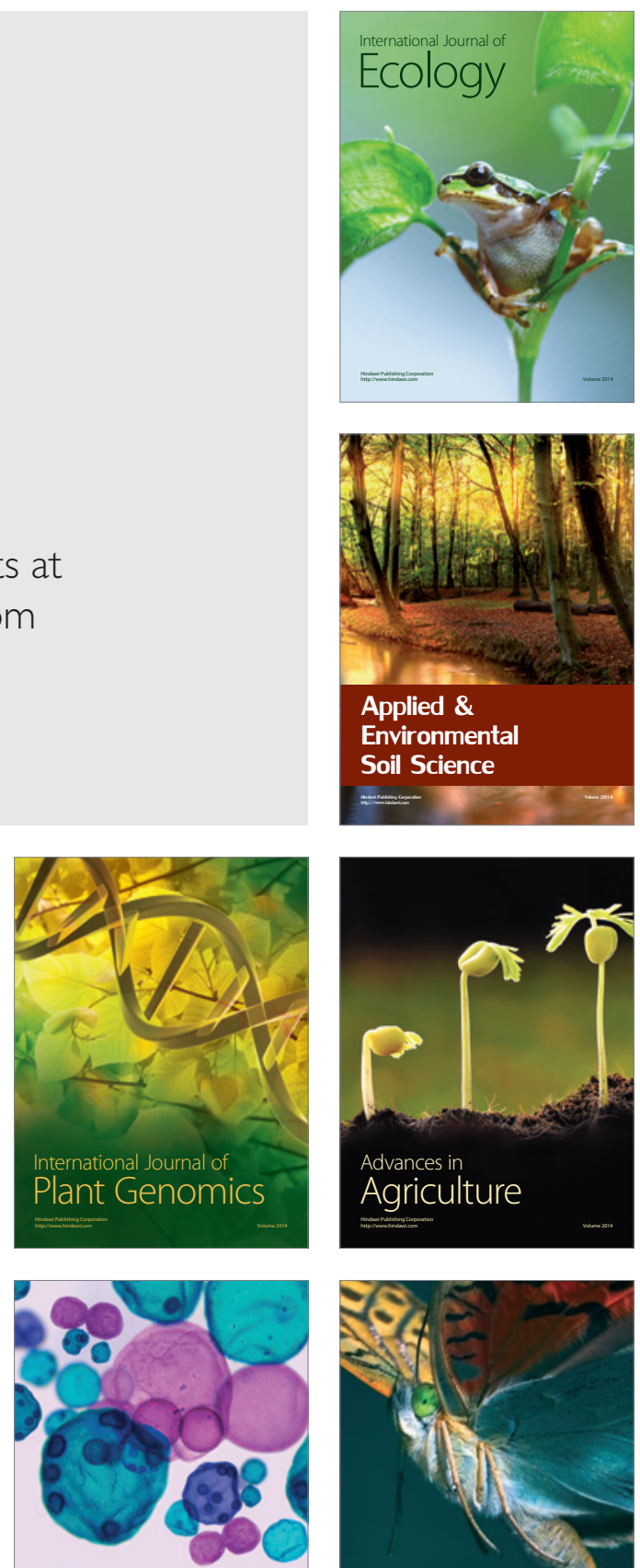

International Journal of Microbiology

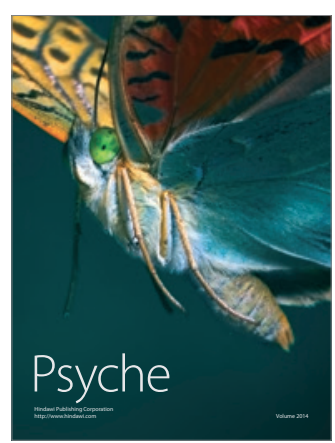

